\author{
UNIVERSIDADE DE SÃO PAULO \\ FACULDADE DE ODONTOLOGIA DE BAURU
}

GUSTAVO SILVA SIÉCOLA

Alterações dentoalveolares em adultos promovidas pelo uso de arco auxiliar de expansão em TMA avaliadas por meio de tomografias computadorizadas

BAURU

2016 



\section{Alterações dentoalveolares em adultos promovidas pelo uso de arco auxiliar de expansão em TMA avaliadas por meio de tomografias computadorizadas}

Tese apresentada a Faculdade de Odontologia de Bauru da Universidade de São Paulo para a obtenção do título de Doutor em Ortodontia.

Área de Concentração: Ortodontia

Orientador: Prof. Dr. José Fernando Castanha Henriques

\section{Versão Corrigida}




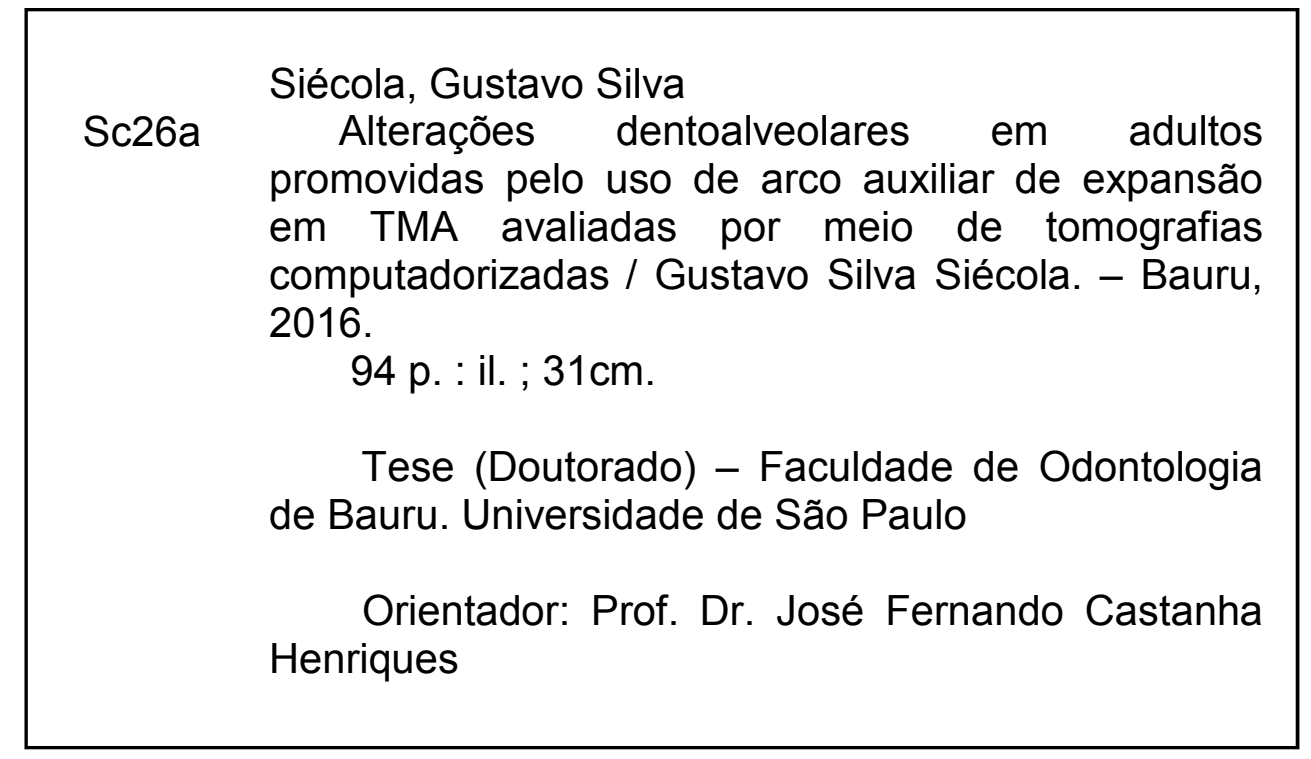

Nota: A versão original desta tese encontra-se disponível no Serviço de Biblioteca e Documentação da Faculdade de Odontologia de Bauru - FOB/USP.

Autorizo, exclusivamente para fins acadêmicos e científicos, a reprodução total ou parcial desta dissertação/tese, por processos fotocopiadores e outros meios eletrônicos.

Assinatura:

Data: 


\section{DEDICATÓRIA}

Dedico este trabalho aos meus alunos e pacientes que diretamente me influenciaram na busca e na vitória de mais esta etapa.

Buscar o conhecimento e saber empregá-lo tanto na prática docente quanto na vida clínica me fez perceber o quanto é grande o universo da Ortodontia, e o quanto não devo parar de buscar.. 



\section{AGRADECIMENTO ESPECIAL}

Agradeço à Deus, que me permitur ter uma familia que respeita seus ensinamentos, que me fez crescer e aprender a sempre desejar e procurar fazer $\sigma$ methor...

Agradeço aos Mens Pais, Paulo e Vanusa, a minha irmã Camila, que sempre me acompanharam e me deram $\sigma$ suporte necessário para vencer mais esta etapa. Espero fazer por merecer a educação e amor que sempre me deram, participando diretamente da construção do men caráter.

Agradeço à Melina, minha esposa, pela sua eterna compreensão e pela sua irretocável forma de ser mulher, amiga, companheira e tutora, me elevando e guiando nas minhas escothas, mostrando-me o caminho...

Agradeço ao mew Orientador, Prof Dr José Fernando Castanha Henriques, pela confiança e pela liberdade em permitir que en executasse men trabalho. Também agradeço aos ensinamento como postura de ser humano e Professor, sabendo sempre com a máxima paciência e educação me guiar nas dificuldades encontradas. Aprendi que respeito não se compra e não se impóe, esim, se conquista.

"O caráter de um homem é formado pelas pessoas que ele escolheu conviver."

Freud 



\section{AGRADECIMENTOS}

Agradeço ao Prof Dr Guitherme Janson, que durante todo este periodo de convivencia me mostrow of caminhos de um pesquisador, as dificuldades que encontrarei e a forma de superálas. Cabe agora fazer jus à estes ensinamentos.

Agradeço à todos os Professores do Departamento de Ortodontia da FOB - USP, pela oportunidade de compartithar grandes momentos de ensinamento.

Agradeço aos funcionários do Departamento de Ortodontia da FOB - USP, que proporcionaram condiçóes ideais para a elaboração deste trabatho e demais atividades inerentes ao curso.

Agradeço aos mens colegas de Doutorado, que cada um a sua maneira contribuiu para meu crescimento profissional, tornando a trajetóría desta fase mais suave com muito mais conhecimento trocados e incorporados.

Em especial, alguns, como Aldo e Diego, pela parcería e ajuda nas publicações, apresentações de seminários e painéis. Espero que o final deste curso seja apenas un recomeço para muitos reencontros profissionais e também de muitos outros bons momentos.

Agradeço também ao colega Willian, que compartithou de algumas dificuldades me dando apoio e tranquitidade para entender.

Agradeço também a Profa Dra Karina Freitas, pela pronta atenção e carinho com que me guiou nas análises estatisticas deste trabalho, esclarecendo numeros em forma de pensamento.

"A grandeza não consiste em receber honras, e sim em merecê-las." 



\section{RESUMO}

A atresia maxilar é um quadro de desarranjo de desenvolvimento do arco dentário presente em diversos tipos de má oclusão, desde as alterações transversais mais simples e puras até as formas mais graves, contemplando as divergências verticais e sagitais. O diagnóstico desta atresia, muitas vezes, é simplificado na presença ou não de mordida cruzada posterior, sendo ela unilateral ou bilateral. No entanto, faz-se necessário uma avaliação mais criteriosa que compreenda não só a própria alteração de forma do arco dentário, mas também as modificações oclusais subsequentes, como relação sagital de classe II ou III de Angle ou as discrepâncias verticais.

Uma das possíveis formas de tratamento ortodôntico está ligada as expansões rápidas da maxila, método de incrementos ósseos por meio de forças ortopédicas, quando o indivíduo ainda apresenta potencial de crescimento craniofacial, ou seja, crianças e adolescentes. Já na vida adulta, esta possibilidade de ganhos ortopédicos não mais está presente e a opção não cirúrgica é o tratamento ortodôntico compensatório, por meio de expansão dentoalveolar do arco maxilar.

O objetivo deste trabalho foi descrever os resultados de expansão dentoalveolar, obtidos utilizando-se o arco auxiliar de expansão em TMA (tungstênio, molibdênio e alloy), a partir de medidas lineares e angulares obtidas, bem como a integridade da cortical óssea vestibular desta área.

Foi realizado um estudo retrospectivo de análise de tomografias computadorizadas, contidas na documentação ortodôntica de 13 pacientes tratados em uma clínica particular, realizadas antes e após a realização desta mecânica de expansão dentoalveolar. Para esta expansão, estes pacientes foram submetidos à instalação de um sobre-arco utilizado por vestibular como um arco auxiliar, sendo justaposto e unido ao fio de nivelamento principal (0,017 $\times 0,025$ " Termoativado) em cinco pontos, sendo 2 pontos nas entradas do tubo dos primeiros molares, 2 pontos entre os pré-molares e 1 ponto entre os incisivos centrais, por meio de fio de amarrilho 0,010" aço. Os resultados apresentaram ganhos estatisticamente significantes para aumento da distância das cúspides ao plano vertical mediano de todos os dentes medidos, bem como aumento da inclinação vestibular destes. A cortical óssea demonstrou adaptação, tendo deslocamento na mesma direção do 

movimento dentário, porém em menor quantidade. O aumento transversal das distâncias inter-dentárias também apresentou aumentos significativos e condizentes com a literatura.

Desta forma, o arco auxiliar de expansão demonstrou-se eficiente para expansão dentoalveolar no paciente adulto, por meio de aumento da inclinação vestibular, com deslocamento dentário maior que o movimento de crista óssea, apresentado ganhos transversais significantes.

Palavras-chave: Expansão maxilar; Ortodontia Corretiva; Atresia maxilar 



\section{ABSTRACT}

The Maxillary constriction is a developmental disorder present in various types of malocclusion, from the most simple and pure transverse changes to the most severe forms, causing vertical and sagittal problems. This malocclusion diagnosis is often simplified in the presence or not of posterior crossbite, which can be uni or bilateral. However, a complete evaluation must include not only the dental arch form changes, but also the subsequent occlusal modifications, such as sagittal relationships of Class II or III malocclusions and vertical discrepancies.

Maxillary constriction treatment can be performed by rapid maxillary expansion, using orthopedic forces when there is still craniofacial growth. In adults, the possibility of orthopedic changes is no longer present and the non-surgical option is compensatory orthodontic treatment with dentoalveolar expansion, when the disorder magnitude allows.

The objective of this study was to evaluate the effects of dentoalveolar expansion, obtained with a TMA (tungsten and molybdenum alloy) auxiliary expansion archwire, by means of linear and angular measurements, and the integrity of the buccal cortical bone in the posterior area.

A retrospective analysis of CT scans, of orthodontic records of 13 patients treated at a private clinic, performed immediately before and after the auxiliary expansion archwire, was used. For the expansion, the patients underwent installation of a secondary arch combined with the primary archwire $(0.017 \times 0.025$-inch heatactivated $\mathrm{Ni}-\mathrm{Ti}$ ), ligated in five points. Two points in the first molar tube entries, 2 points between the premolars and 1 point between the central incisors, with a 0.010 inch steel ligature wire. The results showed statistically significant transverse increase and buccal inclination for all teeth. The cortical bone showed adaptability and displacement in the same direction of tooth movement, but in smaller amounts.

Thus, the auxiliary expansion arch wire proved to be effective to correct dentoalveolar constriction in adult patients, by increasing the buccal dental inclination with larger displacements than the bone crest adaptation and with significant transverse gains.

Keywords: maxillary expansion; corrective orthodontics; maxillary constriction 



\section{LISTA DE FIGURAS}

Figura 1 - Arco auxiliar de expansão.

.47

Figura 2 - Visão clínica do paciente utilizando o arco auxiliar de expansão

Figura 3 - Encaixo em zoom do arco auxiliar ao fio principal de nivelamento

Figura 4 - Exemplo de efeito clínico do arco auxiliar de expansão em TMA

Figura 5 - Exemplo de padronização dos exames de tomografia computadorizada.

Figura 6 - Exemplo de obtenção das medidas lineares usando filtro do programa (flow). 53

Figura 7 - Exemplo de obtenção das medidas angulares usando filtro do programa.

Figura 8 - Exemplos de obtenção de medidas lineares das cristas ósseas. 54

Figura 9 - Exemplo das medidas inter-dentárias 54 



\section{LISTA DE TABELAS}

Tabela1 - Resultados do erro intra-examinador

60

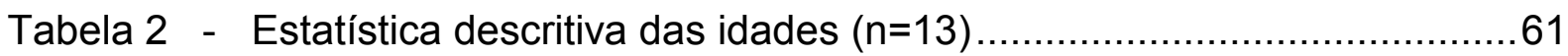

Tabela 3 - Comparação das variáveis do primeiro molar entre as fases

T1 e T2 (teste t dependente) $(n=26)$.

Tabela 4 - Comparação das variáveis do segundo pré-molar entre as fases T1 e T2 (teste t dependente) $(n=24)$.

Tabela 5 - Comparação das variáveis do primeiro pré-molar entre as fases T1 e T2 (teste t dependente) $(n=24)$.

Tabela 6 - Comparação das variáveis do canino entre as fases T1 e T2 (teste t dependente) $(n=26)$. 63

Tabela 7 - Comparação das distâncias inter-dentárias entre as fases T1 e T2 (teste t dependente) $(n=13)$. .64 



\section{SUMÁRIO}

1 INTRODUÇÃO 11

2 REVISÃO DE LITERATURA

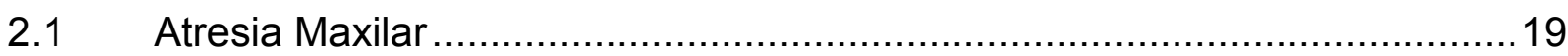

2.2 Uso de tomografia computadorizada na ortodontia ...................................30

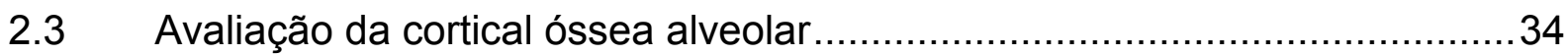

$3 \quad$ OBJETIVO

$4 \quad$ MATERIAL E MÉTODO

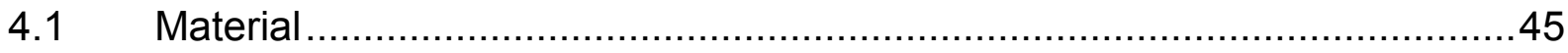

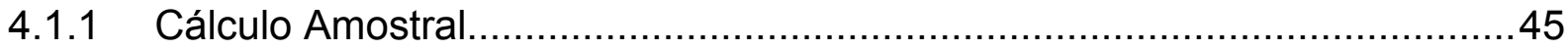

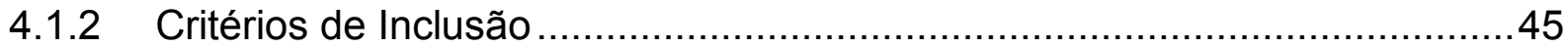

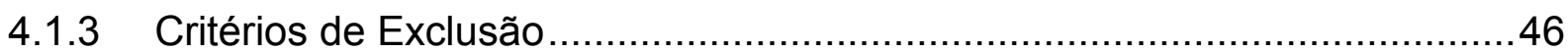

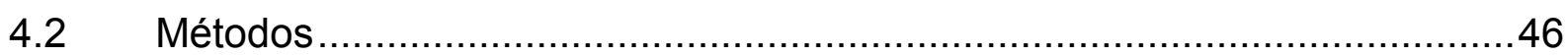

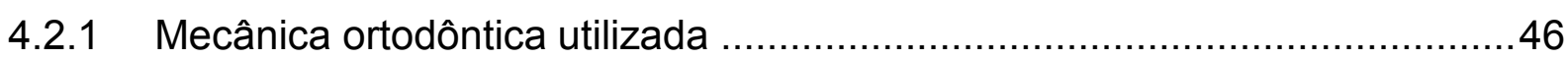

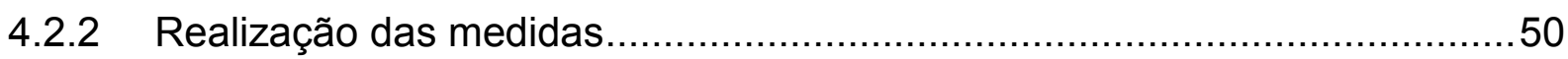

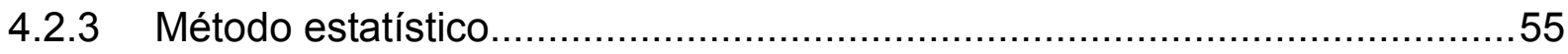

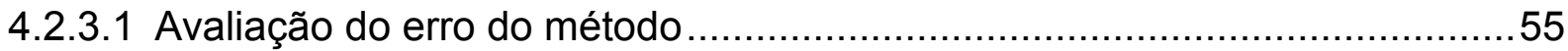

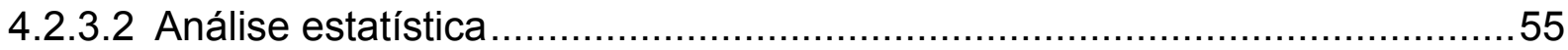

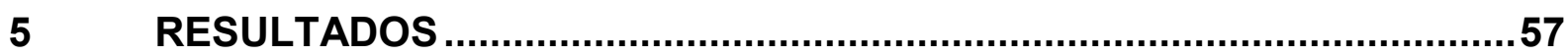

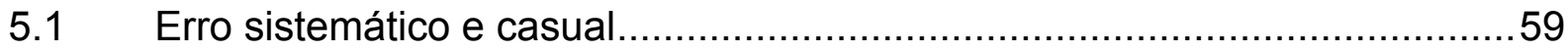

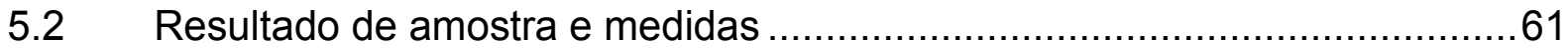

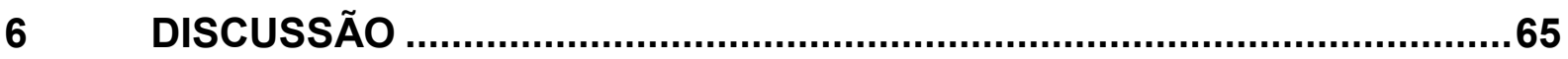

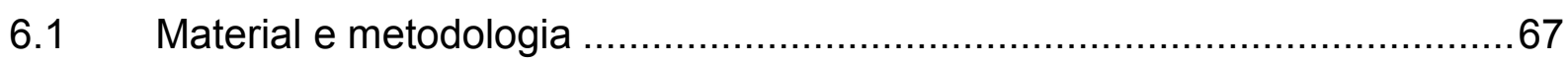

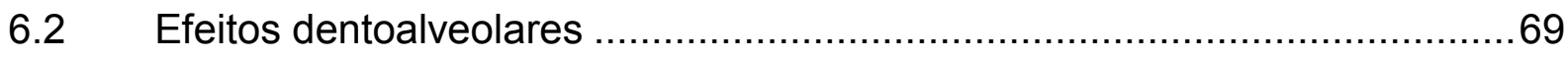

$7 \quad$ CONCLUSÃO

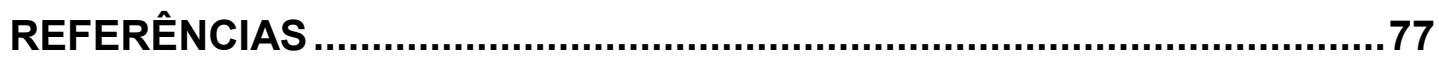

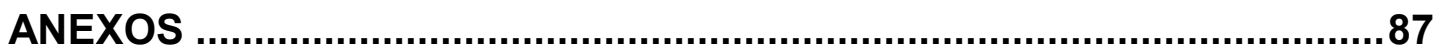



1 INTRODUÇÃO 



\section{INTRODUÇÃO}

A atresia maxilar é uma má oclusão normalmente encontrada em crianças, jovens e adultos (BAKA et al., 2015, BRUNETTO et al., 2013, CORBRIDGE et al., 2011). O diagnóstico desta má oclusão muitas vezes é simplificado na presença ou não da mordida cruzada posterior, sendo ela bilateral ou unilateral (MARTINA et al., 2012). Quando unilateral, o diagnóstico pode ser dividido em verdadeira, quando a atresia maxilar realmente está presente e mesmo o paciente tendo sua mandíbula manipulada em máxima intercuspidação habitual, esta mordida cruzada não se altera. Já na atresia maxilar classificada como tipo funcional, após esta manipulação, surge um contato dentário prematuro, permitindo uma mordida topo-a-topo posterior, que devido à instabilidade, promove o deslocamento lateral da mandíbula (BAKA et al., 2015). Estas alterações de oclusão podem levar o paciente a apresentar padrão alterado e ineficiente de mastigação, além da possibilidade de crescimento craniofacial assimétrico (CORBRIDGE et al., 2011).

O tratamento de eleição para estas más oclusões é a expansão rápida da maxila, que pode ser executada em pacientes ainda em fase de crescimento. Esta intervenção garante ao paciente um sorriso mais estético e uma melhora para as trocas dentárias do segundo período transitório (CORBRIDGE et al., 2011). Para a expansão rápida da maxila são utilizados aparelhos nos quais são aplicadas forças de grande magnitude para que os principais efeitos sejam ortopédicos, garantindo assim ganhos transversais significativos com menor possiblidade de apinhamento (D'SOUZA; KUMAR; SHETTY, 2015, WERTZ, 1970).

Quando esta atresia maxilar se mantem até a vida adulta e, portanto, sem a possibilidade da intervenção ortopédica, a expansão lenta da maxila ou expansão dentoalveolar se tornam opções de tratamento (D'SOUZA; KUMAR; SHETTY, 2015, HUYNH et al., 2009). Nesta situação, aparelhos como Hyrax são utilizados, respeitando o protocolo de ativação lenta, com forças de baixa magnitude, capazes de serem absorvidas pelo próprio ligamento periodontal (AKIN et al., 2014, BAKA et al., 2015, CORBRIDGE et al., 2011, D'SOUZA; KUMAR; SHETTY, 2015, HUYNH et al., 2009, MARTINA et al., 2012). Além deste, outros aparelhos podem ser utilizados 
com o intuito de ganhos transversais dento-alveolares, tais como o quadrihélice, bihélice, arco em "W", sendo todos esses aparelhos fixados na região palatina (HUYNH et al., 2009).

Outro método de expansão dentoalveolar descrito na literatura é o arco auxiliar utilizado principalmente na técnica biofuncional de classe III, sendo este um fio de $0,6 \mathrm{~mm}$ em aço, inserido no tubo auxiliar do acessório ortodôntico dos primeiros molares superiores (tubos soldados nas bandas ou tubos colados) e amarrados com amarrilhos entre incisivos centrais. O intuito deste arco é descruzar a mordida posterior dos pacientes, sendo esta bilateral ou unilateral (PRADO, 2007).

Já o arco auxiliar de expansão em TMA (tungstênio, molibdênio e alloy) foi uma proposta para conseguir os efeitos dento-alveolares destes aparelhos citados anteriormente, com a vantagem de apresentar menos incômodo ao paciente adulto, já que este percorre a mesma posição do fio de nivelamento ortodôntico, como um sobrefio. A opção pelo material TMA se deu pelas características físicas desta liga, por apresentar formabilidade e módulo de elasticidade médio, com liberação de força mais gradativa que quando comparado ao aço (GRAVINA et al., 2013, QUINTAO et al., 2009, URBANIAK et al., 1988). Outra diferença deste desenho de aparelho foi que a força é distribuída por todo o arco de nivelamento, que nesta fase foi o $0.017 \times 0.025$ níquel-titânio termoativado. Respeitando o controle de torque aplicado pelo fio de nivelamento presente nesta fase do tratamento ortodôntico, obteve-se movimento de inclinação controlada dentro do osso alveolar (AKIN et al., 2014, BAYSAL et al., 2013, BRUNETTO et al., 2013, GARIB et al., 2014b, GRAVINA et al., 2013, LEE et al., 2015). A justificava de trabalhar com o arco auxiliar de expansão em TMA (mais flexibilidade que o aço, com liberação de força mais gradual e com formabilidade) associado a um arco de nivelamento retangular e termoativado está ligada as informações destes trabalhos citados, tendo o controle de movimentos de inclinação vestibular pelo fio retangular, embora com folga no "slot" dos bráquetes, para permitir acomodação e remodelação durante o movimento (O'DYWER et al., 2016).

Para a avaliação da movimentação dentária perante forças transversais ortopédicas existe uma vasta literatura demonstrando metodologias e resultados (AKIN et al., 2014, BAKA et al., 2015, BALLANTI et al., 2010, BRUNETTO et al., 
2013, CORBRIDGE et al., 2011, D'SOUZA; KUMAR; SHETTY, 2015, GARIB et al., 2014b, HUYNH et al., 2009, MACHADO JUNIOR; CRESPO, 2006, MARTINA et al., 2012). Os exames de tomografias computadorizadas atendem os métodos de diagnóstico complementar com imagens de grande qualidade e com uma avaliação tridimensional, fato imprescindível atualmente para algumas atividade odontológicas, especialmente a área de implantodontia. Na ortodontia, estes exames ainda são poucos utilizados na prática clinica diária, sendo rotina para alguns profissionais, em casos específicos e de maior complexidade, como no tracionamento de caninos, por exemplo; ou ainda utilizadas no âmbito da pesquisa (CARDOSO MDE et al., 2014, GARIB et al., 2014a). Para avaliar os efeitos dentoalveolares desta mecânica com o fio de TMA, este trabalho seguiu a metodologia descrita na literatura, estabelecendo pontos específicos dentários e cristas ósseas vestibular e lingual, na região de caninos a molar, para medidas lineares e angulares (BAKA et al., 2015).

Com a intenção do detalhamento das medidas e fidedignidade destas imagens tomográficas, os softwares estão cada vez mais avançados e com mais recursos. Para uma correta mediação, estes softwares devem permitir reproduções da imagens de modo multiplanares, reconstrução volumétrica e facilitar os cortes e as medições (AKIN et al., 2014, BARBOSA, 2014, GARIB et al., 2014a, GARIB et al., 2006, GARIB et al., 2005). A literatura aponta a possibilidade de se utilizar o programa OsiriX Lite, v.7.0.3 32-bit, devido a facilidade de obtenção do mesmo, disponível gratuitamente na internet, e principalmente por ser simples, em português e com ferramentas já instaladas para medições lineares e angulares (BARBOSA, 2014).

Assim, considerando que a expansão dentoalveolar em adultos é uma mecânica muito utilizada em casos de atresia dentária e em casos de compensação ortodôntica sagital, a técnica com o arco de expansão auxiliar em TMA vem sendo utilizada na prática clínica, por ser uma opção viável e sem incômodo ao paciente. Porém, a utilização desta mecânica não apresenta resultados evidentes na literatura. Com isso, o intuito deste trabalho foi avaliar os efeitos e alterações dentárias e em nível de crista alveolar desta mecânica, por meio de medidas de exames de tomografias computadorizadas de maxila. 

2 REVISÃo dE LITERATURA 



\section{REVISÃO DE LITERATURA}

\subsection{Atresia Maxilar}

A deficiência transversa dos ossos maxilares, também denominada atresia maxilar, se manifesta pela mordida cruzada uni ou bilateral, parcial ou total, além dos casos em que a mordida cruzada não está presente (LIMA; LIMA FILHO; BOLOGNESE, 2005). Segundo Rossi et al. (2009), esta é comumente acompanhada do desenvolvimento vertical alveolar excessivo, apinhamento dentário, palato profundo e estreito, com largura inferior a $31 \mathrm{~mm}$ de distância inter-molares, região anterior constrita, além de grandes espaços escuros no corredor bucal durante o sorriso, caracterizando a síndrome da deficiência maxilar transversa. A prevalência deste tipo de má oclusão é de $8 \%$ a 23\%, tendo a auto-correção em apenas $16 \%$ dos casos (LINDNER, 1989, ROSSI; ARAÚJO; BOLOGNESE, 2009, THILANDER; MYRBERG, 1973).

A correção precoce das más oclusões de origem transversa deve ser a primeira etapa de um tratamento ortodôntico-ortopédico, seguido das correções das más oclusões de origem vertical e, posteriormente, pelas de origem sagital, considerando, assim, a prevenção da instalação de desvios esqueléticos permanentes (BECHARA et al., 2010). Esta compensação transversal frente às alterações sagitais esqueléticas são notadas na classe II de Angle (ANGLE, 1907) em forma de atresia maxilar, não necessariamente demonstrando uma mordida cruzada posterior uni ou bilateral, uma vez que a mandíbula assume uma postura mais posterior de oclusão. Segundo Thilander e Myrberg (1973), 90\% destas atresias podem apresentar mordida cruzada posterior unilateral quando a mandíbula é manipulada em relação cêntrica, sendo assim, o desvio mandibular deve ser considerado para o diagnóstico correto desta má oclusão (THILANDER; MYRBERG, 1973). Já na classe III (ANGLE, 1907), a posição mais anterior da mandíbula acaba por evidenciar a atresia maxilar, desta forma, o correto diagnóstico se faz necessário também por meio da manipulação dos modelos de gesso, simulando a correção sagital para classe I de Angle (ANGLE, 1907), e assim entender a severidade da atresia, quando presente (ROSSI; ARAÚJO; BOLOGNESE, 2009). Cabe ainda nesta 
etapa do diagnóstico diferenciar o que é atresia esquelética maxilar e o que está relacionada com a simples lingualização dos dentes posteriores (LIMA; LIMA FILHO; BOLOGNESE, 2005, MCNAMARA, 2000).

Uma vez que este desajuste sagital esquelético não está presente de forma marcante e significativa, a ponto de impregnar de maneira desarmônica a face do indivíduo, as expansões ortopédicas para a maxilar e a placa lábio ativa para a mandíbula, em pacientes ainda em fase crescimento craniofacial, têm apresentado resultados expressivo e satisfatórios. Deve-se considerar que uma face harmônica pode apresentar a tão buscada classe I de Angle (ANGLE, 1907) ou ainda, atualmente a face descrita por Andrews (ANDREWS, 1972), que busca o equilíbrio entre o volume de massa dentária e a quantidade de espaço no processo dentoalveolar. Estas expansões ortopédicas tiveram seus primeiros relatos em 1965 por Haas, iniciando uma nova era no tratamento transversal da maxila (HAAS, 1965, 1970).

Com o aprimoramento das pesquisas dos resultados sobre diversos tratamentos ortodônticos, motivou os profissionais ortodontistas a delinearem seus tratamentos em duas grandes e diferentes linhas, sendo uma voltada as extrações dentárias e outra voltada aos procedimentos de expansão dentária ou esquelética (ROSSI; ARAÚJO; BOLOGNESE, 2009). Esta discussão pela melhor escolha de tratamento vem dos primórdios da Ortodontia, desde o debate proposto por Angle (ANGLE, 1907), seguido pelas afirmações de Tweed estabelecendo medidas, angulares e lineares, que definiam a perfeição (TWEED, 1944).

Em relação à linha de tratamento por meio de expansão esquelética, a expansão rápida da maxila (ERM) é geralmente realizada em pacientes durante a fase de crescimento craniofacial, com protocolos de ativação do aparelho expansor 2 vezes ao dia $(0,25 \mathrm{~mm}$ a cada ativação do parafuso expansor), onde a força acumulada é repassada para as linhas de sutura, principalmente para a sutura palatina mediana. O que se espera é que, com este protocolo de ativação, não haja tempo suficiente para o dente se movimentar dentro do próprio alvéolo e portanto, repasse esta força a distância $(100 \mathrm{~N})$, promovendo maior resultado ortopédico e menor movimentação dentária (HUYNH et al., 2009, LINDER-ARONSON; LINDGREN, 1979). 
Os efeitos obtidos no processo de expansão rápida da maxila, em pacientes em crescimento, são descritos vastamente na literatura, demonstrando a separação da maxila em duas metades, com aparecimento de diastema entre os dois incisivos centrais (BARATIERI CDA et al., 2014, GARIB et al., 2006, GARIB et al., 2005, HAAS, 1965, 1970, 1980, HAAS, 2001, SILVA FILHO; PINHEIRO JÚNIOR; CAVASSAN, 1997). Para Silva Filho e colaboradores (1997) os incisivos centrais após o processo ativo inicial da expansão são separados pela segmentação do osso maxilar. No entanto, pela pressão das fibras gengivais, os incisivos centrais tendem a se aproximar, porém apenas com movimento de coroa, fazendo com que eles apresentem aumento em suas angulações. Já no período pós expansão, com a neoformação óssea entre as metades maxilares, as raízes voltam a se aproximar, e então a angulação obtida em excesso no primeiro momento retorna próximo ao inicial (SILVA FILHO; PINHEIRO JÚNIOR; CAVASSAN, 1997). Quanto a ruptura da sutura palatina mediana, um trabalho mais recente, utilizando tomografias de 17 pacientes em idade de crescimento (média 11,2 anos), demonstrou separação completa da maxila, em magnitudes iguais na região anterior e posterior, bem como incrementos na área nasal e divergência de ápices radiculares dos incisivos centrais no intervalo inicial para o pós expansão imediato. As alterações de esqueléticas em nível sutural diminuíram do pós imediato para o período controle (6 meses), porém o aumento da largura nasal se manteve (BALLANTI et al., 2010).

Em relação a expansão lenta da maxila (ELM), esta é normalmente realizada por meio de uso de aparelhos fixos, como o quadrihélice, ou removíveis, como as placas com parafuso expansor. Algumas das vantagens do uso dos aparelhos removíveis refere-se ao menor tempo clínico para a instalação, além da melhor aceitação por parte do paciente, uma vez que é mais fácil sua manipulação durante o período de tratamento. Por outro lado, vários estudos têm relatado que os tratamento realizados com aparelhos fixos, do tipo quadrihélice, são os mais eficazes uma vez que não dependem da cooperação de uso por parte do paciente (BECHARA et al., 2010, HUYNH et al., 2009, ROSSI; ARAÚJO; BOLOGNESE, 2009). Segundo Huynh et al, a expansão lenta da maxila apresenta um protocolo diferente de aplicação de força, com quantidade de ativação menor no mesmo espaço de tempo quando comprada a ERM, promovendo movimentos dentários e esqueléticos em crianças. Este protocolo consiste em 1 ativação do aparelho 
expansor $(0,25 \mathrm{~mm}$ para cada ativação) a cada 2 dias. Neste estudo, os autores descrevem que foram utilizados expansores do tipo Haas e Hyrax, além do expansor tipo quadrihélice, com um molar de ativação, neste protocolo, perfazendo 5 a $20 \mathrm{~N}$ de força, os quais obtiveram resultados similares de expansão, uma vez que todos praticaram o mesmo protocolo (HUYNH et al., 2009).

Fica evidente que com o passar da idade, as sutura palatina mediana começa a ganhar rigidez quanto a abertura, por meio de forças ortopédicas (HUYNH et al., 2009, LINDER-ARONSON; LINDGREN, 1979). Mas não só a idade, mas também o o gênero do paciente pode influenciar o resultado da expansão ortopédica, uma vez que o gênero feminino alcança sua maturidade esquelética mais precocemente que o gênero masculino (HUYNH et al., 2009, PROFFIT, 2000). Desta forma, no final da adolescência e no início da vida adulta, a resistência sutural pode alcançar níveis de difícil ruptura por forças ortopédicas.

Alguns estudos comparam os efeitos da expansão rápida e lenta da maxila, considerando a estabilidade pós tratamento. Vargo et al (2007) demonstraram ganhos efetivos da largura maxilar, com expansão rápida da maxila, durante a fase ativa e com uma manutenção destes incrementos de $86 \%$ na área de caninos no pós-tratamento, favorecendo o alinhamento e nivelamento dentário em fase posterior (VARGO et al., 2007). Este também demonstrou que esta estabilidade póstratamento está ligada à velocidade da expansão, sendo a lenta menos recidivante, associada à presença de crescimento craniofacial por parte do paciente. Ainda neste mesmo estudo, os ganhos na distância inter-molares apresentaram-se estáveis no pós-tratamento em $70 \%$ de sua magnitude, também estando associada à expansão lenta em pacientes jovens. Foi considerada a expansão lenta, mesmo em pacientes com expansor fixo, pois a ativação se deu com $0,25 \mathrm{~mm}$ ( $1 \mathrm{vez}$ ) por semana durante 24 a 32 semanas, tendo portanto $6-8 \mathrm{~mm}$ de expansão. Já para os pacientes que utilizaram o quadrihélice, foram instalados os aparelhos sem ativação prévia e mantidos por 8 semanas, sendo então ativado por $6 \mathrm{~mm}$ ( $3 \mathrm{~mm}$ de cada lado) e mantido por 3 meses, quando foi repetida esta ativação. A seleção por qual tipo de aparelho estava ligada ao tipo de padrão facial, sendo que os dólicofaciais receberam o expansor colado e os mesofaciais e bráquifaciais o tipo quadrihélice. As duas mecânicas trouxeram aumento do perímetro de arco (VARGO et al., 2007). 
Outro estudo mais recente avaliou os incrementos na largura do arco maxilar por meio da expansão rápida (30 pacientes - aparelho tipo Haas), expansão lenta (30 pacientes - nivelamento e arco extrabucal - AEB) e um grupo controle para comparação (30 pacientes) (PINHEIRO et al., 2014). Neste estudo, todos os pacientes encontravam-se em fase de crescimento craniofacial, inclusive o grupo controle. Independente do grupo, houveram aumentos significativos nas distâncias inter-caninos, inter-pré-molares (primeiros e segundos) e inter-molares (primeiros). Estes incrementos foram maiores no primeiro grupo (Haas), sendo significante para região de pré-molares e molares. Em relação a recidiva pós-tratamento, o segundo grupo (expansão lenta) apresentou maior estabilidade, sendo significativa para todas as medidas, com exceção da distância entre os segundos pré-molares. Um dado interessante neste trabalho trata-se do fato de a distância inter-caninos não se alterar significativamente entre os três grupos, embora clinicamente tenha pouca relevância, já que a maioria das mordidas cruzadas posterior acomete pré-molares e molares (HANDELMAN, 1997, WERTZ, 1970). A recidiva da mordida cruzada posterior esteve presente no pós-tratamento (8 anos) em $20 \%$ no grupo 1 e $30 \%$ no grupo 2, por sem significância estatística.

Nesta mesma linha de estudo, Lima Filho e Ruellas (2008) com uma amostra de 70 pacientes em idade de crescimento esquelético (média de 10,4 e 10,6 anos por grupo) demonstraram resultados significantes para o grupo submetido à expansão lenta com arco extrabucal (AEB), expandido 4-8mm, e para o grupo submetido à €om expansão rápida da maxila $(E R M)+A E B$. A diferença média entre inicial e final imediato para o grupo submetido à expansão lenta foi de 2,95mm para distância inter-molares e 1,61 mm para distância inter-caninos, e no grupo submetido à ERM, foi de $5,95 \mathrm{~mm}$ e 2,79mm, respectivamente. Estes resultados demonstraram efeitos satisfatórios na correção da atresia maxilar compensatória a classe II, sendo os resultados com ERM + AEB com maiores magnitudes, e então indicados para casos mais severos, com boa estabilidade a longo prazo(LIMA FILHO; RUELLAS, 2008).

Corroborando com estes achados, Martina et al (2012) pesquisaram os resultados de da expansão rápida e lenta, utilizando um mesmo modelo de aparelho, denominado expansor 2-bandas, onde apenas os $1 \square$ molares permanentes recebem 
banda, sem qualquer tipo de braço para dentes anteriores ou posteriores. Eram indivíduos com idade em crescimento, compondo a amostra em 25 participantes. Para os integrantes do grupo de ERM, foram ativadas 8 ativações (2 voltas completas $-2 \mathrm{~mm}$ ) logo após a cimentação e o tempo de presa do cimento utilizado, sendo apos 3 ativações diárias $(0,75 \mathrm{~mm})$. Já o grupo de ELM, a ativação era 2 vezes na semana $(0,50 \mathrm{~mm})$. Para os dois grupos, a ativação ocorria até uma sobrecorreção de $2 \mathrm{~mm}$ na região molar. Os resultados apontaram incrementos esqueléticos nos dois grupos, com valores de expansão anterior e posterior de 2,2mm, sendo que não houve diferença entre eles, ERM com média 2,4mm na região posterior e 2,5mm na anterior, enquanto que na ELM, 1,9mm e 1,9mm, respectivamente. Vale lembrar que este estudo foi realizado por meio de tomografias computadorizadas tipo cone-beam, trazendo confiabilidade de resultados (MARTINA et al., 2012).

Baka et al (2015) realizaram um estudo para avaliar a eficiência de um expansor modificado para o tratamento da mordida cruzada posterior unilateral verdadeira. Este estudo foi realizado em 39 pacientes, em idade de crescimento craniofacial ainda presente (média 14,7 anos), apresentado dentadura permanente completa. $\mathrm{O}$ intuito desta mecânica foi realizar uma expansão rápida da maxila, com separação de sutura palatina mediana, apresentando maiores efeitos de expansão no lado cruzado. Para isso o protocolo de ativação foi de $1 / 4$ de volta do parafuso expansor 2 vezes ao dia na primeira semana e 1/4 de volta ao dia nos dias restantes necessários para se obter uma relação de cúspide palatina superior com cúspide vestibular inferior dos dentes inicialmente cruzados (média 4-6 semanas). Os resultados apontaram movimentos realmente maiores nos dentes superiores do lado cruzado, com aumentos médios da ponta de cúspide de 3,58mm para área de $1 \square$ pré-molares, $2,86 \mathrm{~mm}$ para $2 \square$ pré-molares e 2,15 para $1 \square$ molares, enquanto que para o ápice radicular estas alterações foram de $3,49 \mathrm{~mm}, 2,93 \mathrm{~mm}$ e $2,35 \mathrm{~mm}$, respectivamente. Os valores obtidos no lado não cruzado foram menores, com significância estatística. Na mesma sequência, os valores para alterações nas áreas de pontas de cúspides foram de $0,81 \mathrm{~mm}, 0,52 \mathrm{~mm}$ e $0,60 \mathrm{~mm}$, enquanto que para as áreas de ápice radiculares foram de $0,43 \mathrm{~mm}, 0,42 \mathrm{~mm}$ e $0,53 \mathrm{~mm}$, respectivamente. Para a execução de todas estas medidas, foram padronizadas as posições de cabeça dos exames tomográficos no próprio programa de medição, fazendo com 
que os exames pré e pós estivessem com os mesmos planos. Para isso, foi utilizado o plano de Frankfurt como referencia inicial, sendo construído o plano sagital mediano como sendo um perpendicular ao plano de Frankfurt e que passasse pelo ponto násio, e o plano frontal, perpendicular aos dois anteriores passando também por násio, o que garantiu a fidedignidade as medidas lineares (BAKA et al., 2015).

Quando se pensa em expansão lenta da maxila, logo se pensa em efeitos meramente em nível dentário. Bechara e colaboradores (2010) realizaram um estudo clínico analisando dois grupos distintos, um submetido ao tratamento da atresia por meio de aparelho expansor do tipo removível e outro grupo submetido ao tratamento com quadrihélice e observaram que ambos provocam ganhos também em nível alveolar, com um aumento significativo das dimensões transversas na maxila e na mandíbula quando comparado os tempos T2 e T1. Observaram também que o uso do aparelho removível promoveu uma expansão do arco maxilar e mandibular, corrigindo assim, a atresia maxilar. Esses achados demonstram que a correção precoce da mordida cruzada posterior tem uma influência positiva no desenvolvimento da maxila, podendo ainda prevenir o crescimento anormal do arco mandibular (BECHARA et al., 2010).

Um fator positivo para a expansão lenta da maxila está no fato de não haver alteração na linha da sutura palatina mediana, no sentido de mantê-la integra, diferentemente da expansão rápida da maxila (ortopédica) onde há a separação da maxila em duas partes (ROSSI; ARAÚJO; BOLOGNESE, 2009). Neste mesmo estudo, foram avaliados 110 modelos de pacientes em dentadura mista e em 3 tempos diferentes, inicial, final imediato e controle com pelo menos 2 anos, utilizando três tipos diferentes de aparelhos, sendo o Haas, o Hyrax e o quadrihélice. Os dois primeiros respeitaram $0,25 \mathrm{~mm}$ de ativação por semana, enquanto que o quadrihélice uma nova ativação a cada 4-6 semanas. Os ganhos transversais foram significantes nos três tipos de aparelho, apresentando-se $3,5 \mathrm{~mm}$ na distancia intermolares e 4,5mm na inter-caninos, sendo que a estabilidade do aumento das distancias inter-caninos foi de $89 \%$, enquanto que da inter-molares foi de $84 \%$. Os autores afirmam que esta estabilidade de incrementos mais anteriores auxilia consideravelmente na fase de irrupção de caninos permanentes, principalmente em casos onde já exista apinhamento primário (ROSSI; ARAÚJO; BOLOGNESE, 2009). 
Outro dado avaliado foi a inclinação dentária dos molares de suporte dos aparelhos, demonstrando uma vestibularização de 4 graus, em média, durante a fase ativa.

Corbrigde et al (2011) realizaram um estudo com 73 pacientes, sendo 39 meninos e 34 meninas, com idade inicial média de 9,2 anos e final de 11,9 anos, avaliando o efeito do quadrihélice em expansão lenta da maxila utilizando tomografias computadorizadas tipo cone-beam. Foi investigado neste estudo as alterações de distância inter-molares, alterações em nível de crista óssea alveolar e osso alveolar, bem como os incrementos na largura maxilar. Os resultados apontaram uma diminuição média da espessura do osso vestibular de 1,6mm, e um consequente aumento médio do osso alveolar palatino, 1,6mm e da largura alveolar em 0,5mm. As alterações médias na distância inter-molares foi um aumento de $6,5 \mathrm{~mm}$ e na largura em nível de palato de 3,9mm. Já no início da fase $2,1 / 3$ dos pacientes não apresentavam osso alveolar em pelo menos um dos lados. Assim, este trabalho que concluiu que a expansão lenta realmente promove aumentos transversais no arco maxilar, com movimentação dentária dentro do alvéolo e diminuição da cortical óssea vestibular (CORBRIDGE et al., 2011).

A literatura aponta que, quando esta má oclusão não pode ser tratada na infância, ou mesmo durante a adolescência, pode ocasionar para a vida adulta uma complicação clínica, com desarranjos não apenas no critério estético, mas também alterações funcionais. Em adultos, a ERM possui limitações e complicações, como a resistência à expansão, ausência ou pequena abertura da sutura palatina mediana, predominância de expansão dentoalveolar em relação ao ganho transverso da base óssea, excessiva inclinação vestibular, de $5^{\circ}$ a $9^{\circ}$ na região dos molares (ROSSI; ARAÚJO; BOLOGNESE, 2009) e extrusão dos dentes postero-superiores; além de absorção da cortical óssea vestibular, recessão gengival, dor, edema, ulcerações e isquemia da mucosa palatal, além de elevado grau de recidiva. É consenso na literatura também que a idade e a maturação esquelética avançada tornam o prognóstico pobre, o que está diretamente relacionada ao grau do efeito ortopédico (HAAS, 1965, 1970, HAAS, 2001, ISERI; OZSOY, 2004, RIBEIRO et al., 2006). Para alguns autores, existe uma idade de limite para a previsibilidade de efeitos ortopédicos, mas o consenso declara o pico de crescimento puberal como referência. Segundo Ribeiro et al (2006) esta idade ideal é por volta dos 13 anos, 
tendo o limite aos 18 anos (RIBEIRO et al., 2006). No entanto, outros autores conseguiram efeitos positivos em adultos maduros, com idade entre 30 e 55 anos, no entanto, sem o sinal clinico patognomônico que é a abertura de diademas entre os incisivos centrais. Nestes indivíduos, observou-se que o aumento da dimensão esquelética transversa do palato, promovido pela ERM, foi pequeno e predominantemente dentoalveolar, e por isso, o sinal clínico de abertura de diastema inter-incisivos centrais, não esteve presente (ROSSI; ARAÚJO; BOLOGNESE, 2009). Outro estudo descreve os resultados de expansão rápida da maxila em um paciente do gênero feminino aos 17 anos, cujo expansor tipo Haas foi modificado durante sua confecção, fazendo com que tivesse como ancoragem primeiros molares e primeiros e segundos pré-molares, todos por meio de banda ortodôntica. Após a expansão, foi observado o diastema clínico durante a fase ativa, caracterizando, assim, os efeitos ortopédicos, além da magnitude do aumento da distância inter-molares de $6,5 \mathrm{~mm}$, o que foi suficiente tanto para correção da mordida cruzada posterior, como também para a melhora da harmonia facial. $O$ autor ressalta que este paciente não relatou qualquer incômodo durante a fase ativa, sem edemas, ou ulcerações e nem mesmo recessão gengival (RIBEIRO et al., 2006).

Com isso, após muitos estudos realizado, é sabido que esta restrição dos efeitos ortopédicos da ERM na fase adulta, tem um aumento dos efeitos dentoalveolares, devido à quantidade e à maturidade das imbricações da sutura palatina mediana. No entanto, atualmente, outros estudos apontam que esta maior resistência à ERM, em indivíduos adultos, está mais associada a união da suturas da maxila com demais ossos, principalmente ao osso zigomático e ao osso esfenóide (ROSSI; ARAÚJO; BOLOGNESE, 2009). Dentro desta perspectiva, a correção da atresia maxilar por alterações dentoalveolares, deslocamento transverso dos ossos maxilares auxiliado por osteotomias ou reposicionamento cirúrgico segmentado da base óssea, deve compensar ou restabelecer a relação esquelética transversa normal entre a maxila e a mandíbula (ROSSI; ARAÚJO; BOLOGNESE, 2009). Esta correção na fase adulta busca recuperar uma oclusão funcional, com estabilidade a longo prazo. E é neste momento que duas possibilidades de mecânica ortodôntica se fazem presente, sendo uma delas a expansão rápida da maxila assistida cirurgicamente (ERMC) e a outra, mais conservadora, a 
compensação transversal dentoalveolar, conseguida por expansão dentária. Para tanto, a magnitude da constrição maxilar, a presença ou não de mordida cruzada posterior, bem como, as inclinações dentárias prévias, são características a serem avaliadas para a determinação de qual planejamento o clínico deverá optar.

Caracterizando a magnitude como fator determinante da escolha do tipo de expansão, Handelman et al (2000) descreveram a necessidade cirúrgica para ganhos transversais maiores que $8 \mathrm{~mm}$. Dentro da expansão rápida da maxila no adulto com intervenção cirúrgica existem dois protocolos de osteotomia. A osteotomia parcial da maxila é ligeiramente menos invasiva, uma vez que apenas libera as áreas de maior resistência óssea para que então o dispositivo expansor já instalado consiga seus efeitos. Já a osteotomia Le Fort I segmentada tem o objetivo de separas a maxila dos osso adjacentes, separá-la e promover movimentação lateral das parte assumindo a correção da atresia já no ato cirúrgico (BELL; EPKER, 1976, CAPELOZZA FILHO et al., 1996, HANDELMAN et al., 2000). O tipo de cirurgia deve estar relacionada ao grau de severidade da má oclusão, comprometimento ou não severo de desarmonia facial a ponto de necessitar de cirurgia ortognática, entre outros fatores. A recidiva da osteotomia Le Fort I segmentada apresenta menor estabilidade quando comparada a osteotomia parcial (FISH; EPKER, 1986, HAAS, 1980).

Por outro lado, a ERM também pode ser realizada em indivíduos adulto, com maiores efeitos dentários, de acordo com a maturidade esquelética do indivíduo. Estes efeitos dentários são caracterizados principalmente por inclinação vestibular dos dentes posteriores de suporte dos aparelhos expansores. De acordo com alguns estudos, esta inclinação vestibular apresenta-se instável no controle pós-tratamento, demonstrando índices de recidiva de até 63\% (HANDELMAN, 1997), levando ao aparecimento de contatos oclusais do tipo topo-a-topo, decorrente da pressão exercida pela musculatura peribucal, sendo que a manutenção dos resultados alcançados ao longo do tempo, constitui um grande desafio clínico. Em contrapartida, indivíduos em fase de crescimento craniofacial possuem maior estabilidade do tratamento, quando comparados aos adultos e adolescentes com maturação esquelética avançada (HANDELMAN, 1997, HANDELMAN et al., 2000). 
Os resultados descritos na literatura quando avaliadas as ERM em adultos demonstram magnitudes diferentes. Capelozza Filho et al.(CAPELOZZA FILHO et al., 1996) demonstraram ganho transverso de $3,26 \mathrm{~mm}$ e $1,46 \mathrm{~mm}$ nas distâncias inter-molares e inter-caninos, respectivamente. Já Handelman et al (2000) descreveram valores superiores, em média de 5,9mm de expansão dentária na região dos primeiros molares e de $2,8 \mathrm{~mm}$ na região dos caninos.(HANDELMAN et al., 2000) É sempre válido relembrar que $80 \%$ dessas alterações foram dentoalveolares, ou seja, inclinação vestibular dos dentes posteriores e sem aparecimento de diastemas entre os incisivos centrais. Ainda neste estudo, foram descritos valores semelhantes no critério inclinação vestibular na região dos molares, tanto para protocolos com ERM, como já citado acima ( $5^{\circ}$ a $\left.9^{\circ}\right)$, como para protocolo com arcos de nivelamento expandidos, estando estes próximos a 3,1 \pm $5,7^{\circ}$ e $4 \pm 3,9^{\circ}$ de cada lado na inclinação vestibular dos primeiros molares e processos dentoalveolares, respectivamente. Desta forma, os autores afirmam que, casos onde exista a discrepância transversal maxilar e os dentes posteriores já assumam inclinações vestibulares compensatórias, ficaria contra-indicada qualquer uma das metas terapêuticas descritas, seja por arcos diagramados ou por ERM, pois a estabilidade destas inclinações seria pobre (CAPELOZZA FILHO et al., 1996, HANDELMAN et al., 2000).

Já Machado Junior e Crespo avaliaram por meio de telerradiografias de norma frontal 12 pacientes adultos, com idade entre 18 anos e 2 meses e 37 anos e 8 meses, em dois tempos, sendo inicial e após expansão lenta da maxila. Foi demonstrado incrementos na distância inter-molares por volta de 2,00mm com tempo médio de 5,3 meses, tendo também incrementos na largura maxilar de 2,42mm. O protocolo de dispositivo deste trabalho foi por meio de aparelhos removíveis, com recobrimentos palatino e dentário, e ativação de $1 / 4$ de volta por dia $(0,25 \mathrm{~mm})$. Nada foi descrito a respeito de inclinações dentárias (MACHADO JUNIOR; CRESPO, 2006).

Estes procedimentos compensatórios estão indicados para pacientes que apresentem, preferencialmente, dentes posteriores-superiores lingualizados, ou ainda, bem posicionados, com saúde gengival e sem recessões (RIBEIRO et al., 2006), já que o processo alveolar parece acompanhar as pequenas movimentações 
dentárias resultantes da expansão (HANDELMAN et al., 2000). A literatura aponta que a compensação dentária pode ser uma forma de correção da atresia maxilar, em adultos com discrepância transversa suave (até $4 \mathrm{~mm}$ na região dos molares), por meio da qual os arcos de nivelamento são coordenados para promover $1 \mathrm{~mm}$ de expansão, nos segmentos postero-superiores e, $1 \mathrm{~mm}$ de contração nos posteroinferiores, de cada lado (BETTS et al., 1995).

\subsection{Uso de tomografia computadorizada na Ortodontia}

O uso da tomografia computadorizada na elaboração de diagnósticos e ainda na avaliação dos efeitos de mecânicas ortodônticas e determinadas limitações das mesmas vem trazendo novas perspectivas de interpretação de resultados (ARANAFERNANDEZ DE MOYA et al., 2006, GARIB et al., 2014a, GARIB et al., 2007a, JUNQUEIRA et al., 2015).

Para que se entenda melhor a real diferença das tomografias computadorizadas (TC) e as radiografias normais, basta entender que as radiografias são exames uni-planares, e que as TC são multiplanares, permitindo então subdividir o exame em "fatias", determinando outro nível de detalhamento com capacidade tridimensional (GARIB et al., 2007a).

Existem dois tipos de tomografia computadorizada, sendo a tradicional e a tipo feixe cônico (cone-beam - CBCT). A única semelhança entre eles está na utilização da radiação $x$ e na possibilidade de exames em cortes, sendo então varias as diferenças, desde o tamanho físico do equipamento até o tipo e forma de obtenção das imagens. A TC tradicional é o tipo de tomografia utilizada para obtenção de exames de qualquer parte do corpo. Seu equipamento é composto de uma mesa, onde acomoda o paciente, uma parte de emissão de radiação $x$ e um anel com sensor (conjunto denominado gantry) que capta o resultado destas radiações, sendo então transferidas à um computador, normalmente localizado fora da sala de exame e separada por um vidro plumbífero. Este aparelho emite radiações em feixe estreito (colimado) e em forma de leque, tendo a mesa alterando sua posição para a obtenção da próxima imagem adjacente, a próxima "fatia". Já os 
equipamentos atuais, a mesa se movimenta junto com a tomada do exame, simultânea a emissão da radiação $x$, promovendo um movimento helicoidal, o que denomina os exames atuais, como tomografia computadorizada helicoidal ou espiral. Este avanço trouxe rapidez na obtenção e melhora na resolução das imagens. Algumas situações podem atrapalhar a resolução destes exames. Existe uma unidade de medida que trata-se da menor espessura dos cortes deste exames, denominado voxel e, portanto, quanto menor o voxel, maior a quantidade de detalhes, e maior o tempo para obtenção. Outra unidade de medida é o pixel, que ainda é uma medida uni-dimensional, por não representar a profundidade do corte. Quando existem estruturas metálicas, como restaurações dentárias, os exames ficam impregnados por raios em diversos tons de cinza, dificultado a interpretação das estruturas nesta área do exame. Este tipo de tomografia só não é utilizada de rotina devido ao alto custo e as altas doses de radiação (GARIB et al., 2007b).

O segundo tipo de tomografia computadorizada, denominada feixe cônico ou cone-beam (CBCT), é especialmente importante e utilizada para a área odontológica. Isso acontece devido ao menor tamanho do equipamento e também ao menor custo para obtenção. O tempo total de obtenção do exame pode ser de 10-70 segundos, porém o tempo de exposição a radiação é bem menor, de 3-6 segundos. Os aparelhos modernos tomam os exames com o paciente sentado, na grande maioria dos equipamentos, ou também deitados. A obtenção das imagens acontece com a emissão de radiação $\mathrm{x}$ em torno da cabeça do paciente, com o anel receptor girando $360 \square$ ao redor, formando uma imagem base semelhante a telerradiografia e em seguida sendo reconstruída em 3D por um software instalado no computador que processará estas imagens. Outra vantagens é que estas imagens após o processamento serão armazenadas no formato DICOM (Digital imaging and communication in Medicine), e assim, qualquer professional que tenha um programa especifico para este formato pode tranquilamente manipular e interpretá-las em seus diversos cortes. Quando comparada a dose de radiação, este modelo de feixe cônico demonstra necessidade menor de tempo de exposição, e quando comparada as radiografias normais, sua radiação assemelha-se a sequencia de radiografias periapicais boca toda. A grande vantagem é que com este exame tomográfico, com radiação semelhante, o profissional consegue por meio de análise no programa realizar todos os demais exames complementares de uma 
documentação ortodôntica, por meio de cortes, conseguindo uma imagem semelhante a telerradiografia de norma lateral ou frontal, e mesmo uma radiografia panorâmica, sem contar o fato da possibilidade de obtenção de imagens volumétricas (ARANA-FERNANDEZ DE MOYA et al., 2006, GARIB et al., 2007b, JUNQUEIRA et al., 2015).

Segundo alguns estudos, dentro das inúmeras aplicações da CBCT, algumas podem ser evidenciadas como: a avaliação do posicionamento tridimensional de dentes retidos e sua relação com os dentes e estruturas vizinhas; a avaliação do grau de reabsorção radicular de dentes adjacentes a caninos retidos; a visualização das tábuas ósseas vestibular e lingual e sua remodelação após movimentação dentária (ARANA-FERNANDEZ DE MOYA et al., 2006, GARIB et al., 2007a).

Frente a todas estas possibilidades, durante a requisição do exame pelo profissional, o mesmo deve determinar qual a dúvida a ser investigada, para que o técnico responsável colha o exame, realizando os cortes necessários e laude de maneira direta. Cabe também ao profissional avaliar o custo-benefício para a requisição deste exame, já que ainda se trata de um investimento de maior valor financeiro por conta do paciente quando comparado a uma documentação ortodôntica convencional.

Depois de obtido o exame tomográfico, várias são as formas de avaliá-lo. Uma projeção de máxima intensidade (MIP) é uma forma de representação que permite "buscar / encontrar" uma estrutura anatómica específica dentro do exame completo. A partir de um corte determinado, avalia-se cada voxel por meio do volume de dados, discriminando variações de tons de cinza (atenuação do voxel). Assim, em casos de pequenos detalhes e com áreas de superfícies metálicas, como as restaurações, pode haver distorção e mascarar um processo carioso, por exemplo. Já a reconstrução multi-planar (MPR) permite ao avaliados navegar e percorrer os determinados cortes da área selecionada, permitindo leituras finas e precisas (ARANA-FERNANDEZ DE MOYA et al., 2006).

Considerando a possibilidade de obtenção de telerradiografías para exame cefalométrico e averiguar a fidedignidade, Junqueira et al realizaram um estudo piloto com 09 tomografias de face toda, que foram divididas em hemifaces direita e 
esquerda, para posterior mensurações de grandezas lineares e angulares, por 2 examinadores previamente selecionados. Dentre os 3 grupos, face total e cada hemiface (direita e esquerda), com grande nível de concordância entre os avaliadores, não foi notada qualquer diferença estatisticamente significante entre os valores descritos. Fato importante a ressaltar neste trabalho é que a amostra era composta por pacientes sem assimetria de face aparente (JUNQUEIRA et al., 2015). Este trabalho reforça a possibilidade de a partir da tomografia computadorizada de feixe cônico a obtenção de outros exames complementares bidimensionais com grande fidedignidade.

Uma outra grande vantagem dos exames realizados com tomografia computadorizada é a capacidade de avaliar em detalhes efeitos de mecânicas determinadas, avaliando tanto os efeitos dentários quanto os efeitos em nível esqueléticos e em graus minimalistas, como a avaliação das cristas ósseas alveolares. Para isso é necessário entender os cortes sagitais, axiais e coronários, para se determinar com exatidão a leitura do corte. Mais importante ainda é a padronização da posição da cabeça para a execução do exame, mas também após a leitura do exame no programa específico de medições, determinando planos e linha padronizadas para o exame pré e pós do mesmo paciente. A confiabilidade destas medidas também é descrita na literatura com alto potencial, inclusive para métodos de planejamento de tratamento, como instalação de implantes em áreas restritas (BARBOSA, 2014).

A grande maioria dos trabalhos descritos na literatura foram realizados com tomografia de face toda, o que permite fazer a padronização e até mesmo a superposição dos exames em tempos diferentes a partir de estruturas da base do crânio, área imutável frente as mecânicas ortodônticas, e, portanto, de grande fidedignidade para tal função. Algumas padronizações ocorrem durante a execução dos exames, pelo próprio aparelho (CAPPS et al., 2015, GARIB et al., 2006, GARIB et al., 2005), enquanto outras acontecem pelo ajuste da imagem no próprio programa de medição (AKIN et al., 2016, AKIN et al., 2014, BAKA et al., 2015, JOHARI; KAVIANI; SAEEDI, 2015, MARTINA et al., 2012). 


\subsection{Avaliação da cortical óssea alveolar}

O estudo da espessura da cortical óssea ganhou possibilidade de avaliação junto com o aumento do uso das tomografias computadorizadas, especialmente do tipo cone-beam.

Alguns estudos estão interligados as mecânicas ortodônticas e seus efeitos (CARDOSO MDE et al., 2014, GARIB et al., 2014a, GARIB et al., 2007a, GARIB et al., 2006, GARIB et al., 2005, GARIB et al., 2012, LORENZONI et al., 2012, RAPOSO et al., 2011, YATABE et al., 2015), enquanto outros estão investigando variações anatômicas de acordo com características de crescimento (JOHARI; KAVIANI; SAEEDI, 2015, OZDEMIR; TOZLU; GERMEC-CAKAN, 2013).

Com o intuito de melhorar o conhecimento sobre as corticais ósseas e as densidades destas nos exames radiográficos, Andruch e Planchta (2015) avaliaram a qualidade do osso maxilar por meio de alterações de escala de cinza em exames tomográficos do tipo cone-beam. Forma avaliados 20 pacientes, 8 homens e 12 mulheres, todos adultos (19-73 anos). Os resultados apontaram valores de maiores densidades ósseas nas corticais vestibular, palatina e osso trabeculado, nesta ordem de maneira decrescente. Este estudo também avaliou a região anterior e posterior da maxila de maneira separadamente. As implicações clinicas deste trabalho inferem maiores densidades ósseas e por consequência, maior mineralização, na região mais anterior da maxila que na região posterior, e na cortical vestibular maior que na cortical palatina (ANDRUCH; PLACHTA, 2015).

Ozdemir, Tozlu e Germec-Cakan (2013) estudaram a correlação entre a espessura de cortical óssea da área de caninos e mesial de $2 \square$ molares permanentes e o tipo de crescimento facial, dólicofacial, mesofacial ou bráquifacial. Foram utilizados 155 exames de tomografias computadorizadas tipo cone-beam, divididos em 3 grupos de acordo com o crescimento craniofacial e medidas as corticais vestibulares e palatinas nas regiões acima descritas. $O$ trabalho apresentou algumas alterações da espessura de cortical óssea nas medidas realizadas quando correlacionadas ao tipo de crescimento, sendo que os valores medidos em pacientes com padrão bráquifacial apresentou maior espessura nas áreas de caninos e $1 \square$ pré-molares, a área dos $2 \square$ pré-molares mostrou-se menor nos dólicofaciais e na 
região dos molares manteve-se a tendência, sendo maiores para bráquifaciais e menores para dólicofaciais (OZDEMIR; TOZLU; GERMEC-CAKAN, 2013).

Outro trabalho corroborou com estes achados, também demonstrando correlação entre o tipo de crescimento vertical do indivíduo e espessura da cortical, trabalho este realizado por meio de tomografias computadorizadas tipo cone-beam. Da mesma maneira, indivíduos dólicofaciais demonstraram espessuras mais finas de cortical óssea, além da largura de rebordo também respeitar esta tendência. Já os indivíduos com tendência a crescimento bráquifacial demonstraram cortical óssea vestibular e lingual mais largas e largura de rebordo também maiores (JOHARI; KAVIANI; SAEEDI, 2015).

Corroborando com estes resultados, Garib et al $(2006,2014)$ avaliaram a influência do movimento dentário na manutenção ou alteração de espessura e nível do periodonto de suporte. Também foi demonstrada uma menor espessura de cortical vestibular / labial e lingual nos pacientes com crescimento hiperdivergente quando comparado aos hipodivergentes. Neste trabalho também foi demonstrado que pacientes adultos tendem a apresentar deiscência óssea com mais facilidade que pacientes jovens, principalmente na região dos incisivos inferiores. Isso acontece pelo fato de que movimentos de inclinação vestíbulo-lingual deslocam o elemento dentário do centro do osso alveolar, podendo causar diminuição em altura da tabua óssea vestibular ou lingual. O tipo de movimento vestíbulo-lingual apresenta correlação com o aparecimento das deiscências ósseas, demostrando a incapacidade de neoformação ósseas sub-perióstea por vestibular nestes tipos de movimentos (GARIB et al., 2006, GARIB et al., 2014b). A consequência clinica destas deiscências são as recessões gengivais, embora estas não aconteçam imediatamente após a perda em altura do osso cortical. Isso é explicado pelo aumento do tecido conjuntivo, deixando-o mais longo, e o epitélio funcional entre o tecido gengival e a junção amelo-cementária se mantem na mesma espessura, principalmente em casos onde não existiu inflamação gengival. Assim, movimentos de protrusão de incisivos (CHEN et al., 2010) e expansão de arco dentário por meio de inclinações vestibulares podem promover deiscências ósseas (FUHRMANN, 2002, YATABE et al., 2015). Este mesmo estudo ainda esclarece que mecânicas de expansão maxilar rápida ou lenta em pacientes adultos tendem a provocar 
deiscência nos dentes posteriores e de suporte do aparelho utilizado, especialmente em pacientes que já apresentavam esta cortical vestibular fina ao início do tratamento (GARIB et al., 2006, GARIB et al., 2005). O dente mais acometido pela deiscência é o $1 \square$ pré-molar, pela própria anatomia da maxila, e pela maior tendência de movimento de corpo deste dente e pela estrutura da cortical óssea desta área ser mais fina (GARIB et al., 2006).

Um estudo que compara os tipos de expansores, verificou que o aparelho tipo Hyrax (dento-suportado) demonstrou mais efeito de vestibularização dentária e consequente maior afinamento de cortical vestibular que o aparelho tipo Haas (dento-muco-suportado), porém sem significância estatística. Estes resultados demonstraram uma diminuição de 0,6 a $0,9 \mathrm{~mm}$ da cortical vestibular e um aumento de 0,8 a 1,3mm por palatino. Estas medidas foram realizadas por meio de exames tomográficos, com reconstrução multiplanares, sendo que a área de medição foi padronizada pela altura da trifurcação do $1 \square$ molar superior direito. Assim, as medidas foram realizadas da cortical vestibular a raiz e da raiz a cortical palatina, nos dentes caninos, $1 \square$ pré-molares, $2 \square$ pré-molares e $1 \square$ molares permanentes, em dois grupos distintos, onde 4 meninas foram submetidas ao tratamento com expansor tipo Haas e outras 4 meninas com expansor tipo Hyrax. Os exames tomográficos foram realizados imediatamente antes da expansão e 3 meses após. Também foi avaliado o nível da crista óssea alveolar, medindo da ponta de cúspide a crista, sendo observado que os dentes mais acometidos, deste afinamento de cortical vestibular, foram os dentes de suporte direto, sendo os $1^{\circ}$ pré-molares e os $1 \square$ molares permanentes; enquanto que as corticais ósseas dos caninos e 2 prémolares não demonstraram alterações em espessura significativas. Quanto ao nível, os $1 \square$ pré-molares também se mostraram o mais acometidos, e isso é explicado por estar numa área mais estreita do osso alveolar maxilar (GARIB et al., 2006).

Baka et al (2015) também avaliaram as alterações das cristas corticais vestibulares e palatinas, sendo medidas até o plano sagital mediano, por meio de medidas bilaterais, para a avaliação dos diferentes resultados no tratamento da assimétrica maxilar, com mordida cruzada unilateral. Para o lado cruzado, que apresentou maiores alterações dentárias, as cristas ósseas vestibulares alteraram sua posição na área de $1 \square$ pré-molares em $3,64 \mathrm{~mm}, 2 \square$ pré-molares em $2,96 \mathrm{~mm}$ e 
na área de $1 \square$ molares em 2,79mm; enquanto que no lado não cruzado, que teve maior ancoragem, apresentou menor movimentação, sendo de 0,68mm, 0,40mm e 0,69mm, respectivamente. Já pelo lado palatino, as alterações também ocorreram, sendo no lado cruzado na área de $1 \square$ pré-molares em 2,93mm, $\square \square$ pré-molares em $3,15 \mathrm{~mm}$ e na área de $1 \square$ molares em $2,29 \mathrm{~mm}$, enquanto que no lado não cruzado, $0,51 \mathrm{~mm}, 0,48 \mathrm{~mm}$ e 0,53mm, respectivamente (BAKA et al., 2015). Estes aumentos das distâncias entre as cristas ósseas vestibulares e palatina do plano sagital mediano podem ser explicados pela tendência que existe flexão deste osso alveolar frente as forças expansionistas (AKIN et al., 2014, BAKA et al., 2015). 

3 OBjetivo 



\section{OBJETIVO}

O objetivo deste trabalho foi descrever os efeitos de inclinação e translação dos dentes posteriores, durante o processo de ganhos transversais dentoalveolares por meio do arco auxiliar de expansão em TMA, bem como avaliar a integridade e alterações da cortical óssea vestibular desta área. 

4 MATERIAL e MÉtOdo 



\section{MATERIAL E MÉTODO}

\subsection{MATERIAL}

\subsubsection{Cálculo Amostral:}

Realizou-se cálculo amostral baseado em dados de pesquisa similar disponível na literatura (BAKA et al., 2015). Assim, como estimativa do desvio padrão considerou-se o maior desvio padrão para as alterações transversais encontradas nesta pesquisa, erro alfa de $5 \%$, erro beta de $20 \%$, chegando ao valor de $n$ igual 13 pacientes. Desta maneira, as tomografias computadorizadas de maxila selecionadas dos arquivos compreendem pacientes de 18 a 44 anos, sendo, portanto, 26 exames complementares, 13 pré imediato e 13 pós imediato a utilização do arco auxiliar de expansão em TMA.

\subsubsection{Critérios de Inclusão:}

Estes pacientes foram selecionados de um arquivo da clinica particular deste pesquisador, denominada Corporal Line, situada na Rua Bartolomeu de Gusmão, 885, Jardim América, cidade de Bauru - SP. Os pacientes participantes foram esclarecidos e de livre consentimento permitiram a utilização de seus exames complementares prévios, entre eles fotografias extra e intra bucais realizadas antes e durante o tratamento ortodôntico, bem como as tomografias computadorizadas no momento especifico do uso deste arco auxiliar. Além disso, foram também selecionados a partir dos seguintes critérios de inclusão:

- Pacientes sem tratamento ortodôntico prévio

- Pacientes que não apresentaram quebras / solturas dos bráquetes e/ou bandas ortodônticas durante o período especifico da utilização do arco auxiliar de expansão em TMA

- Pacientes com atresia dentoalveolar compensatória de classe I, II ou III de Angle 


\subsubsection{Critérios de Exclusão:}

- Presença de mordida cruzada posterior esquelética sem potencial compensatório;

- Presença de atresia maxilar severa, onde o tratamento de eleição fosse a expansão maxilar assistida por cirurgia;

- Presença de recessão gengival por vestibular no início do tratamento ortodôntico;

- Pacientes que ainda estivessem em crescimento;

- Pacientes que não apresentassem os exames complementares completos, sendo eles fotografias extra e intrabucais, exames radiográficos iniciais e tomografias computadorizadas pré e pós imediatos a utilização do arco auxiliar de expansão em TMA.

\subsection{MÉTODO}

\subsubsection{Mecânica ortodôntica utilizada:}

Todos os pacientes tiveram seu tratamento ortodôntico conduzidos pelo mesmo profissional, na mesma clinica privada, com todos os exames complementares realizados no mesmo centro de documentação ortodôntica.

A técnica ortodôntica utilizada para o tratamento também foi padronizada, sendo a técnica Straight Wire, na prescrição Roth para os pacientes que utilizaram bráquetes SLI (sistema auto-ligável) da marca Morelli (11 pacientes), e na prescrição Capelozza I, para pacientes com bráquetes convencionais também da marca Morelli (2 pacientes), assim como a mesma sequência de fios de nivelamento. 
A sequência de fios foi a seguinte:

- 0.014 " NiTi termoativado $35^{\circ}$ (permanência de 1 a 2 meses, dependente do grau de apinhamento inicial)

- $\quad 0.018 "$ NiTi termoativado $35^{\circ}$

- $\quad 0.016 \times 0.022 " \mathrm{NiTi}$ termoativado $35^{\circ}$

- $\quad 0.017 \times 0.025^{\prime \prime} \mathrm{NiTi}$ termoativado $35^{\circ}$

Neste estágio do nivelamento, foi realizada a tomografia computadorizada de maxila caracterizando o exames complementar prévio a utilização do arco auxiliar de expansão.

Após, foi inserido o arco auxiliar de expansão em TMA, confeccionado em fio $0,8 \mathrm{~mm}$ redondo, retificado, sem curvatura inicial. Em suas extremidades foram confeccionados uma dobra tipo helicoide em $90^{\circ}$ graus com o alinhamento do arco, sendo que estas dobras deveriam estar em contato com a entrada do tubo de nivelamento dos primeiros molares superiores, direito e esquerdo. Assim, o fio de nivelamento principal $(0.017 \times 0.025$ " NiTi termoativado) passaria por dentro deste helicoide e então entraria no tubo ortodôntico dos primeiros molares superiores, bilateralmente. Além destes pontos de união, fios de amarrilhos 0.010"aço também foram utilizados para unir o arco auxiliar ao arco de nivelamento principal, na área entre os pré-molares bilateralmente e entre os incisivos centrais superiores, conforme fotografias ilustrativas abaixo (Fig 1-3). A força liberada por este arco de expansão foi de aproximadamente $250 \mathrm{~g}$.

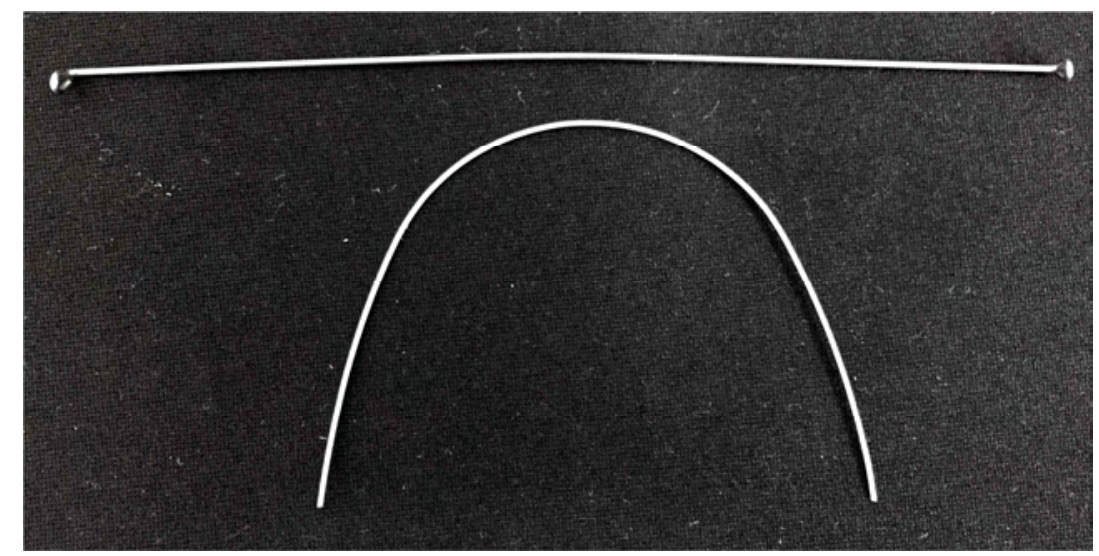

Figura 1 - Arco auxiliar de expansão. 
O tempo médio de utilização deste arco de expansão foi de 60 dias. Os resultados considerados satisfatórios foi a melhora da atresia dentoalveolar superior, obtendo uma forma de arco maxilar mais compatível com a normalidade. Como limite máximo deste expansão dentária foi a relação de topo-a-topo das cúspides palatinas dos dentes posteriores superiores com as cúspides vestibulares dos dentes posteriores inferiores. (Figura 4)

Uma vez obtido estes resultados, o paciente não mais utilizou este arco auxiliar e recebeu uma fio de nivelamento $0.019 \times 0.025$ " aço diagramado passivamente na nova dimensão transversal obtida e com tratamento térmico de revenido, garantindo maior estabilidade dimensional ao fio. Neste momento o paciente repetiu o exame de tomografia computadorizada, tendo então o exame final desta mecânica.

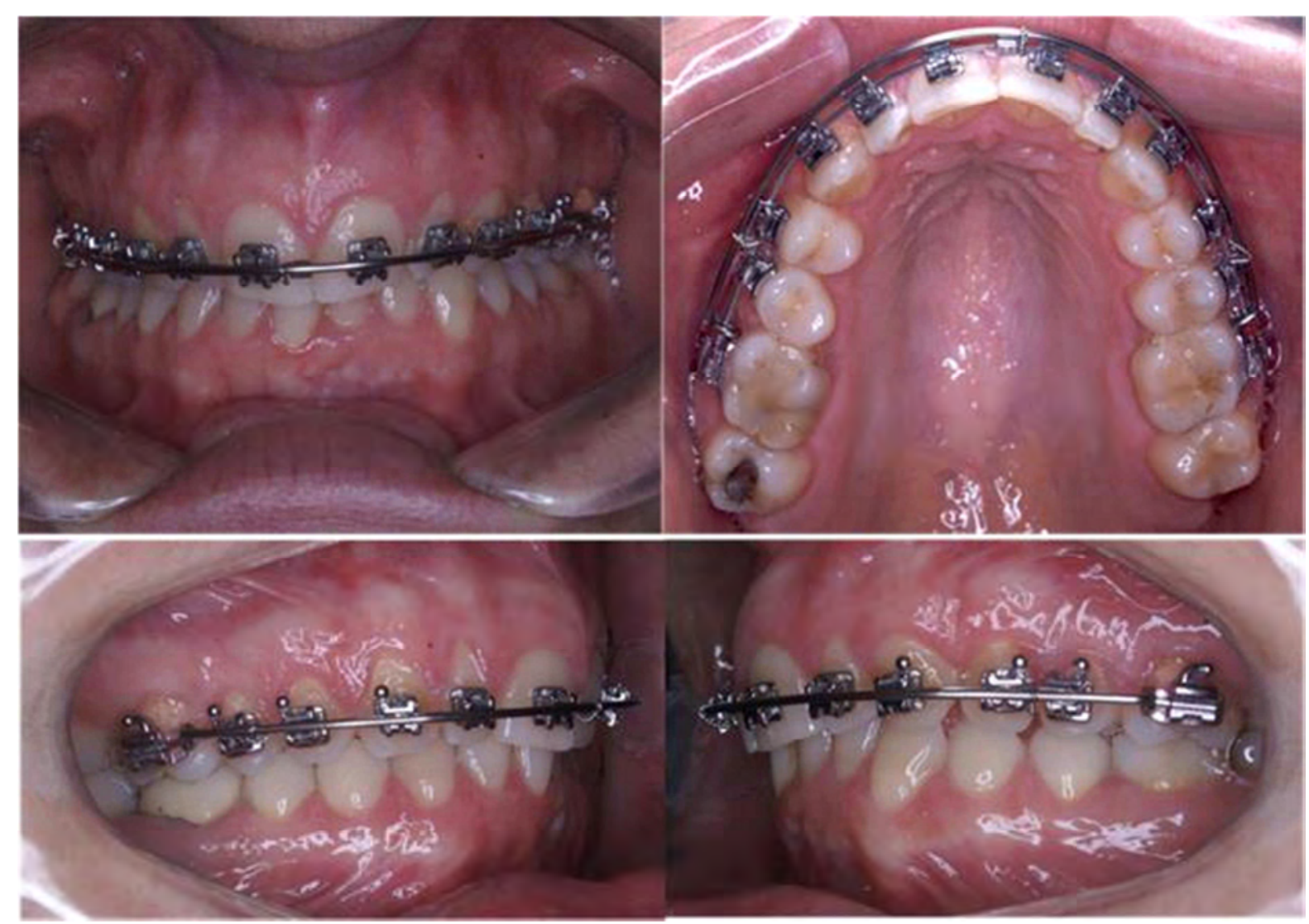

Figura 2 - Visão clínica do paciente utilizando o arco auxiliar de expansão 

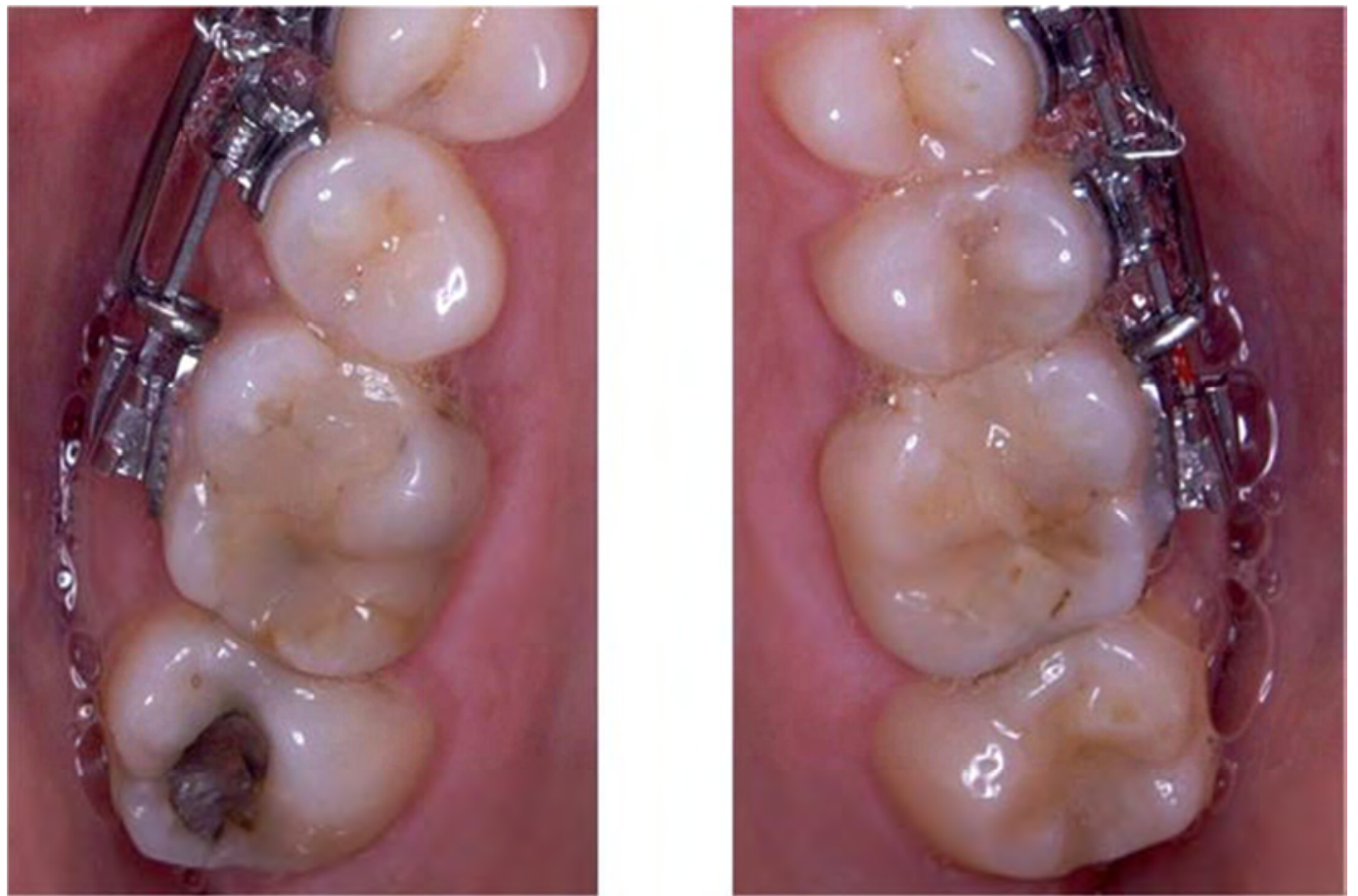

Figura 3 - Encaixo em zoom do arco auxiliar ao fio principal de nivelamento

Deste momento em diante, os pacientes foram conduzidos ao término do tratamento ortodôntico de modo convencional, respeitando a técnica proposta inicialmente.
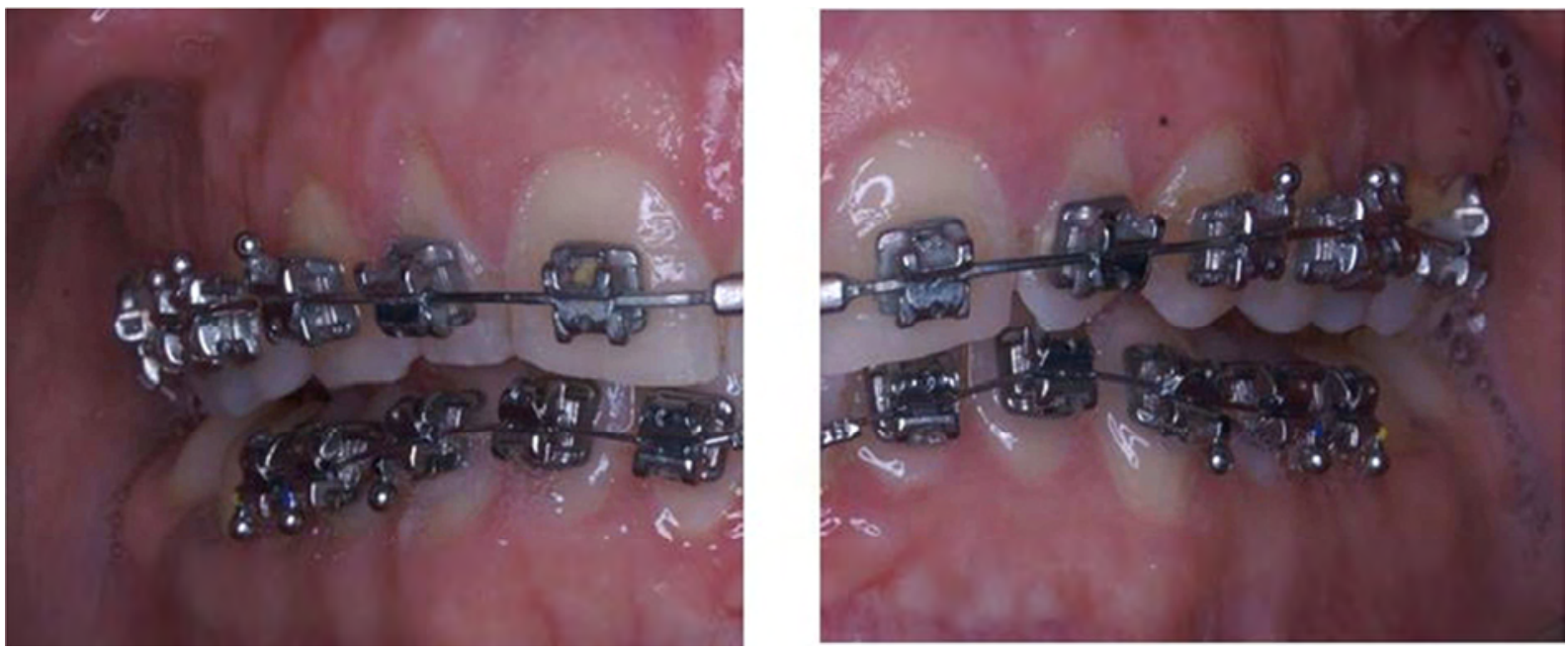

Figura 4 - Exemplo de efeito clínico do arco auxiliar de expansão em TMA 


\subsubsection{Realização das medidas:}

Para não haver variação nos resultados, tomou-se o cuidado de selecionar pacientes cuja documentação ortodôntica, incluindo os exames de tomografia computadorizada de maxila, tenha sido realizada no mesmo centro de documentação. Além disso, o técnico em radiologia havia sido orientado a manter a posição natural de cabeça, observando também a angulação adequada desta em cada paciente, durante as tomadas das tomografias obtidas. O aparelho utilizado para estes exames foi o modelo I-CAT, da marca KAVO. Todos os exames foram salvos em mídia removível com as imagens em formato DICOM, com cortes de $0.25 \mathrm{~mm}$.

Com base na literatura, o programa selecionado para a realização das medidas das imagens tomográficas foi o OsiriX Lite, versão v.7.0.3 32-bit, instalado em um Macbook Pro, tela de 13 polegadas, processador de 2,7 GHz Intel Core i7, com 8 GB RAM, Intel HD Graphics 3000512 MB.

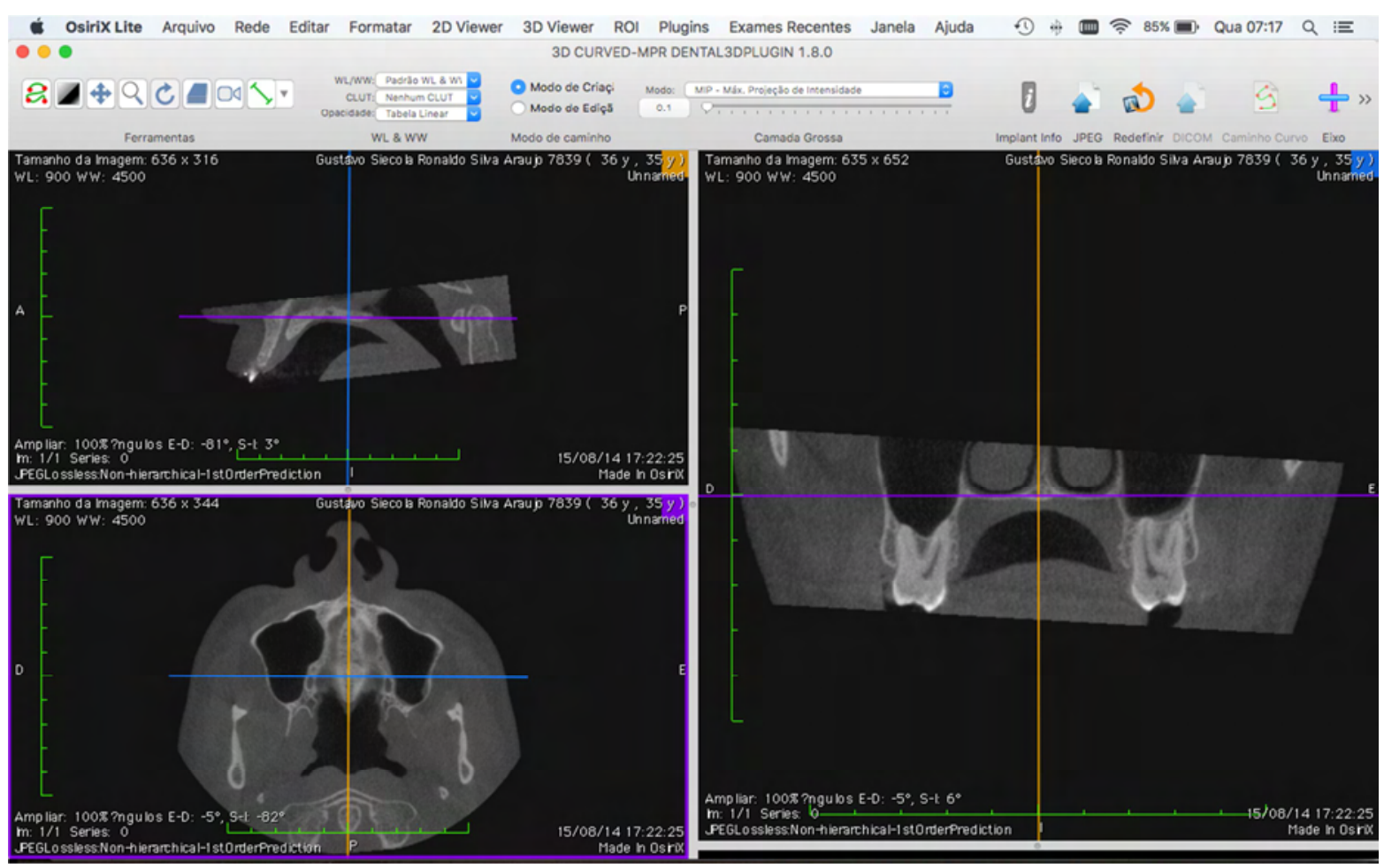

Figura 5 - Exemplo de padronização dos exames de tomografia computadorizada 
O programa escolhido permitiu a visualização de imagens multiplanares, porém, antes de se iniciar as medições nas imagens da tomografia da maxila, foram estabelecidos planos de referência horizontais e verticais, assim como já citados em estudos anteriores, os quais relatam que plano de Frankfurt foi utilizado como plano horizontal e, o plano vertical, foi construído passando pelo ponto násio e perpendicular a este plano de Frankfurt (AKIN et al., 2014, BAKA et al., 2015). Porém, para este trabalho, algumas alterações em relação ao estabelecimento destes planos foram realizadas, já que as imagens utilizadas neste estudo foram apenas da maxila. Assim, o plano horizontal foi estabelecido pelo plano palatino (espinha nasal anterior - ENA e espinha nasal posterior - ENP) no corte axial e, perpendicular a este, em $90^{\circ}$ graus com o ponto mais inferior e posterior do forame incisivo, de maneira que este ponto foi demarcado na primeira imagem vindo da ENP para a ENA onde o forame apresenta-se com seu trajeto completamente aberto. A partir da posição vertical dos pacientes foi estabelecido um plano vertical mediano ( $P V M)$, como referência para as medidas realizadas, centralizando este plano com a ENA e ENP no corte axial, ajustando para correção de giro da cabeça durante o exame. Já no corte coronal, para padronização da cabeça, usou-se como referência o contorno palatino na área dos $2^{\circ}$ molares permanentes, ajustando a imagem para que este ficasse paralelo ao plano estabelecido pelo plano palatino no corte axial.(Figura 5) Com isso, as medidas foram realizadas percorrendo os cortes coronais, com o intuito de encontrar os pontos necessários e medí-los até o plano vertical mediano (PVM). Para a obtenção das medidas, alguns filtros foram utilizados, para melhor contraste as estruturas, como os filtros flow e perfusion. Seguindo a mecânica ortodôntica utilizada neste estudo, os pontos de referência para a obtenção destes planos não foram alterados, aumentando a confiabilidade das medidas obtidas.

Para esta pesquisa, as medidas lineares foram assim divididas, seguindo metodologia descrita em trabalho anterior (BAKA et al., 2015): 


\section{Medidas externas:}

- Cúspide mesial e vestibular do $1^{\circ}$ molar superior ao PVM

- Cúspide vestibular do $2^{\circ}$ pré-molar superior ao PVM

- Cúspide vestibular do $1^{\circ}$ pré-molar superior ao PVM

- Cúspide vestibular do canino superior ao PVM

- Ápice radicular mesial e vestibular $1^{\circ}$ molar superior ao PVM

- Ápice radicular vestibular $2^{\circ}$ pré-molar superior ao PVM

- Ápice radicular vestibular $1^{\circ}$ pré-molar superior ao PVM

- Ápice de canino superior ao PVM

- Crista alveolar vestibular ao PVM

- Crista alveolar vestibular ao plano palatino - vertical

\section{Medidas internas:}

- Crista alveolar palatina ao PVM

- Crista alveolar palatina ao plano palatino - vertical

Para a obtenção das alterações em inclinação vestibular, as medidas angulares foram assim obtidas (BAKA et al., 2015):

\section{Medidas angulares:}

- Cúspide mesial e vestibular do $1^{\circ}$ molar superior ao ápice radicular mesial ao PVM

- Cúspide vestibular do $2^{\circ}$ pré-molar superior ao ápice radicular ao PVM

- Cúspide vestibular do $1^{\circ}$ pré-molar superior ao ápice radicular ao PVM

- Cúspide vestibular do canino superior ao ápice radicular ao PVM

Outras medidas lineares realizadas foram as distâncias inter-dentárias, sendo elas entre caninos, primeiro pré-molares, segundo pré-molares e entre os primeiro molares. Para a execução destas medidas optou-se pelo ponto de referência a área de união do acessório ortodôntico na superfície vestibular de cada dente até a mesma área do dente homologo no outro quadrante. A justificativa para esta padronização será explicada na discussão deste trabalho.(Figura 9) 


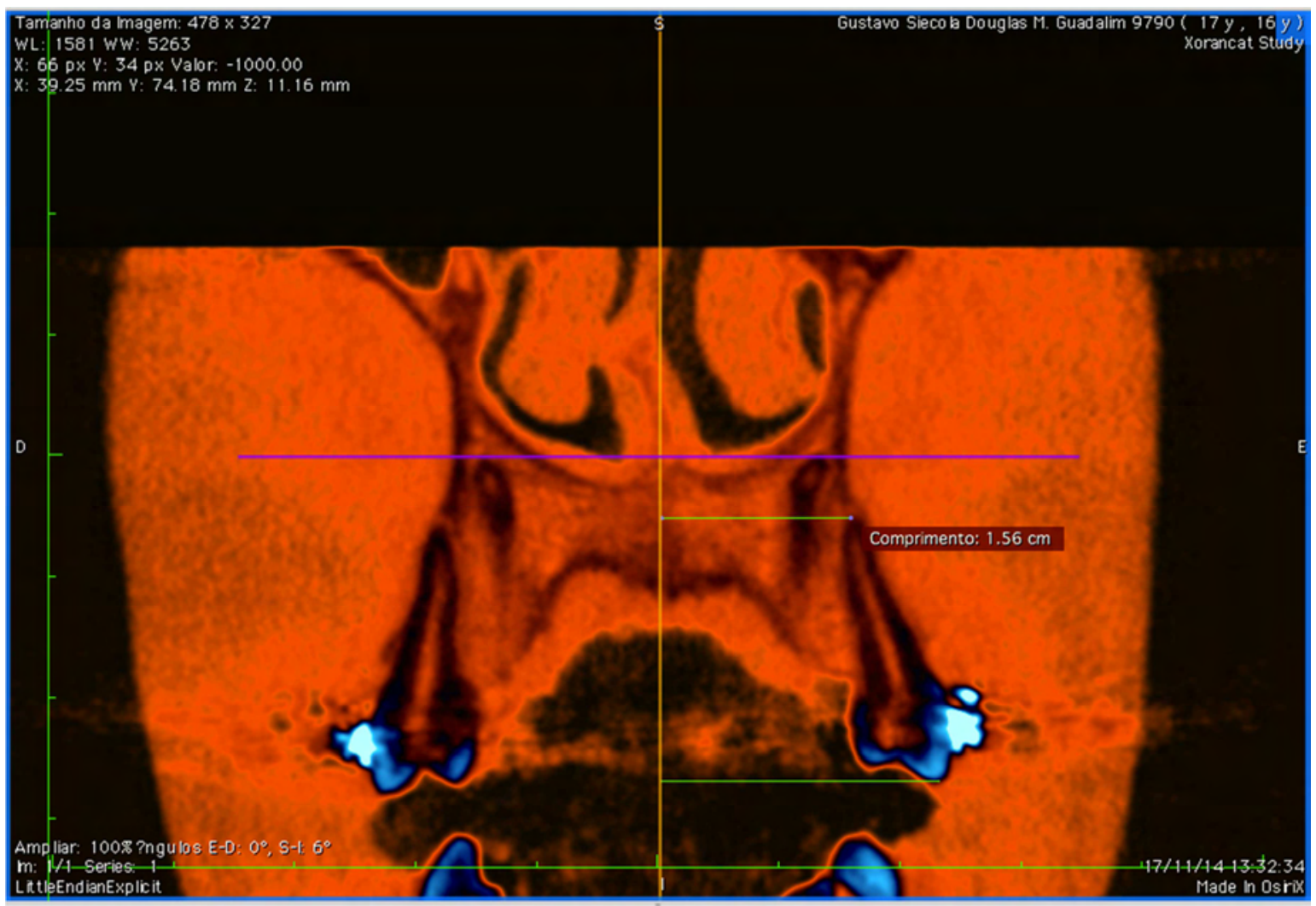

Figura 6 - Exemplo de obtenção das medidas lineares usando filtro do programa (flow).

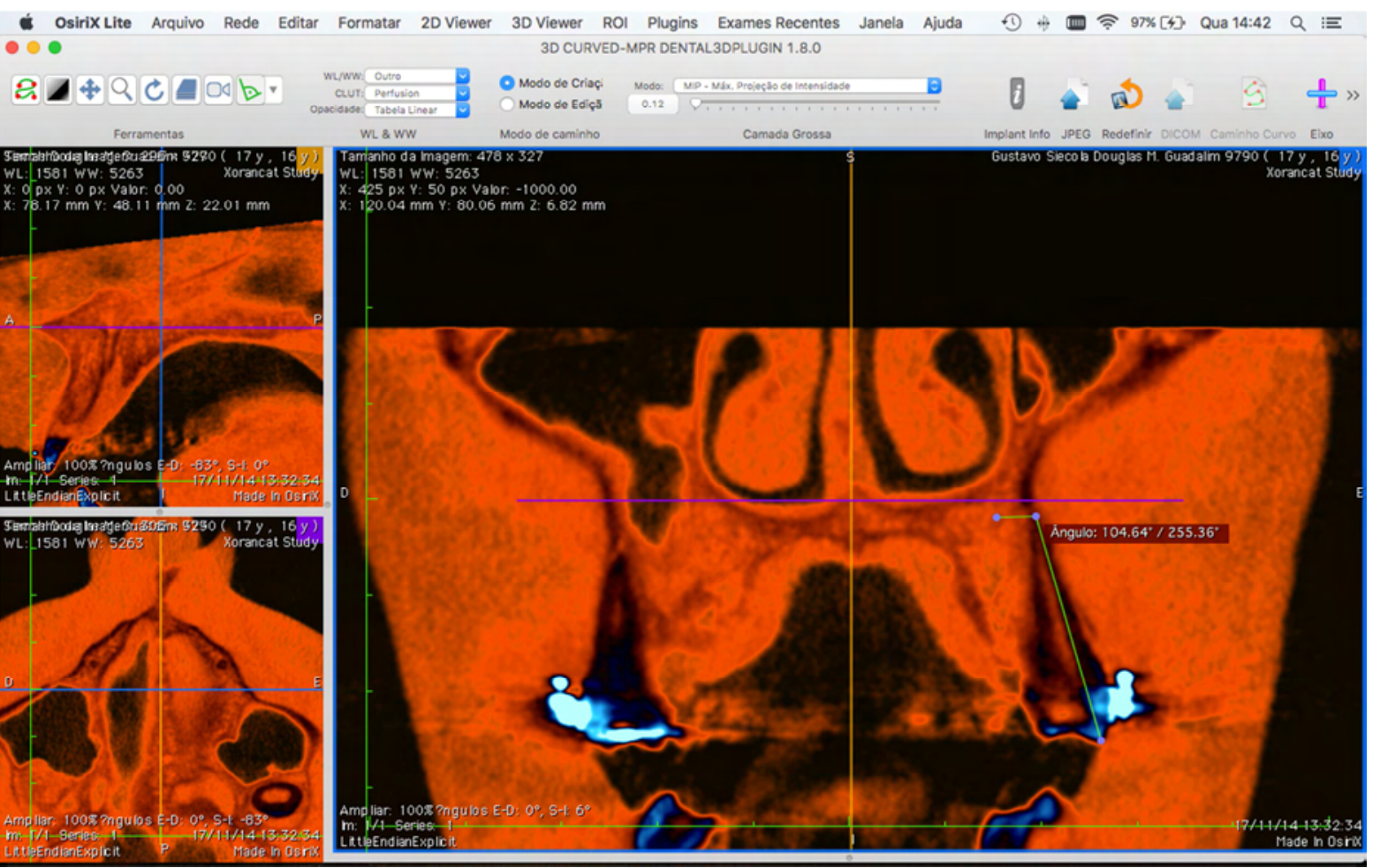

Figura 7- Exemplo de obtenção das medidas angulares usando filtro do programa. 


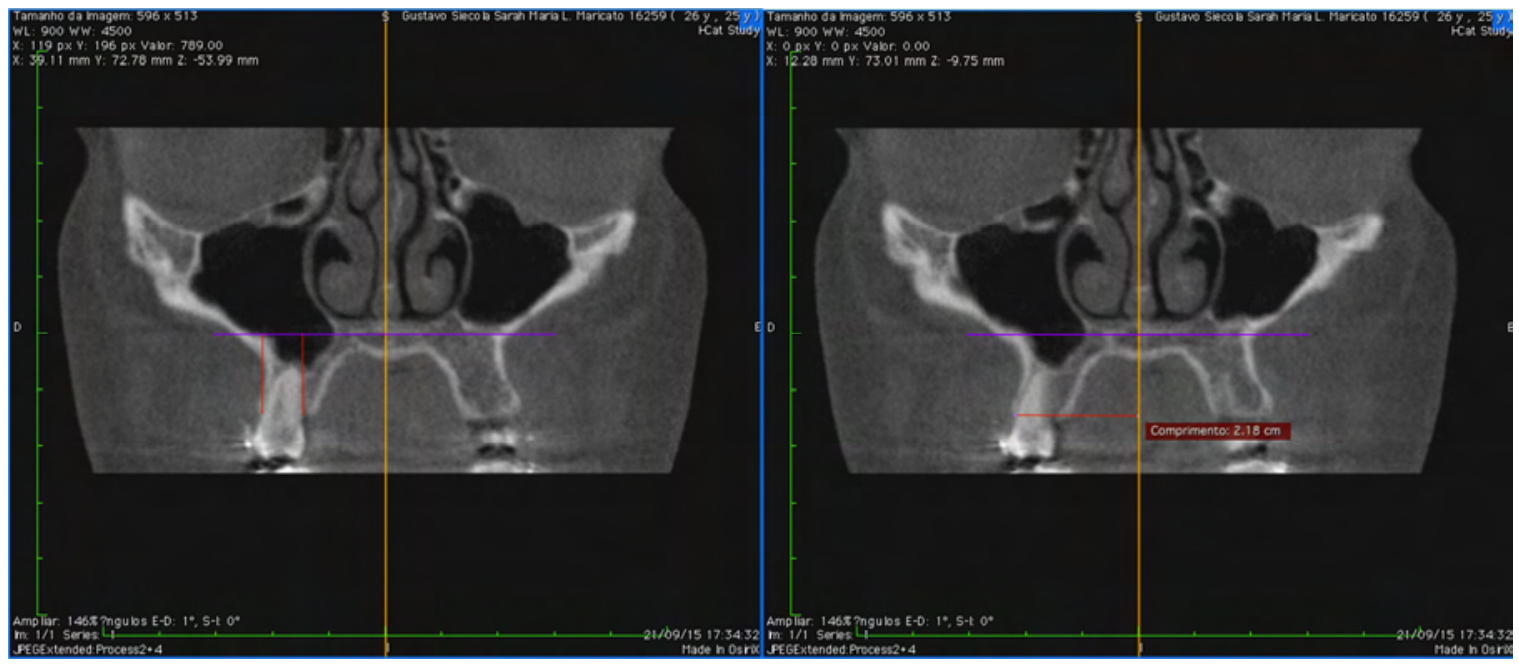

Figura 8 - Exemplos de obtenção de medidas lineares das cristas ósseas.

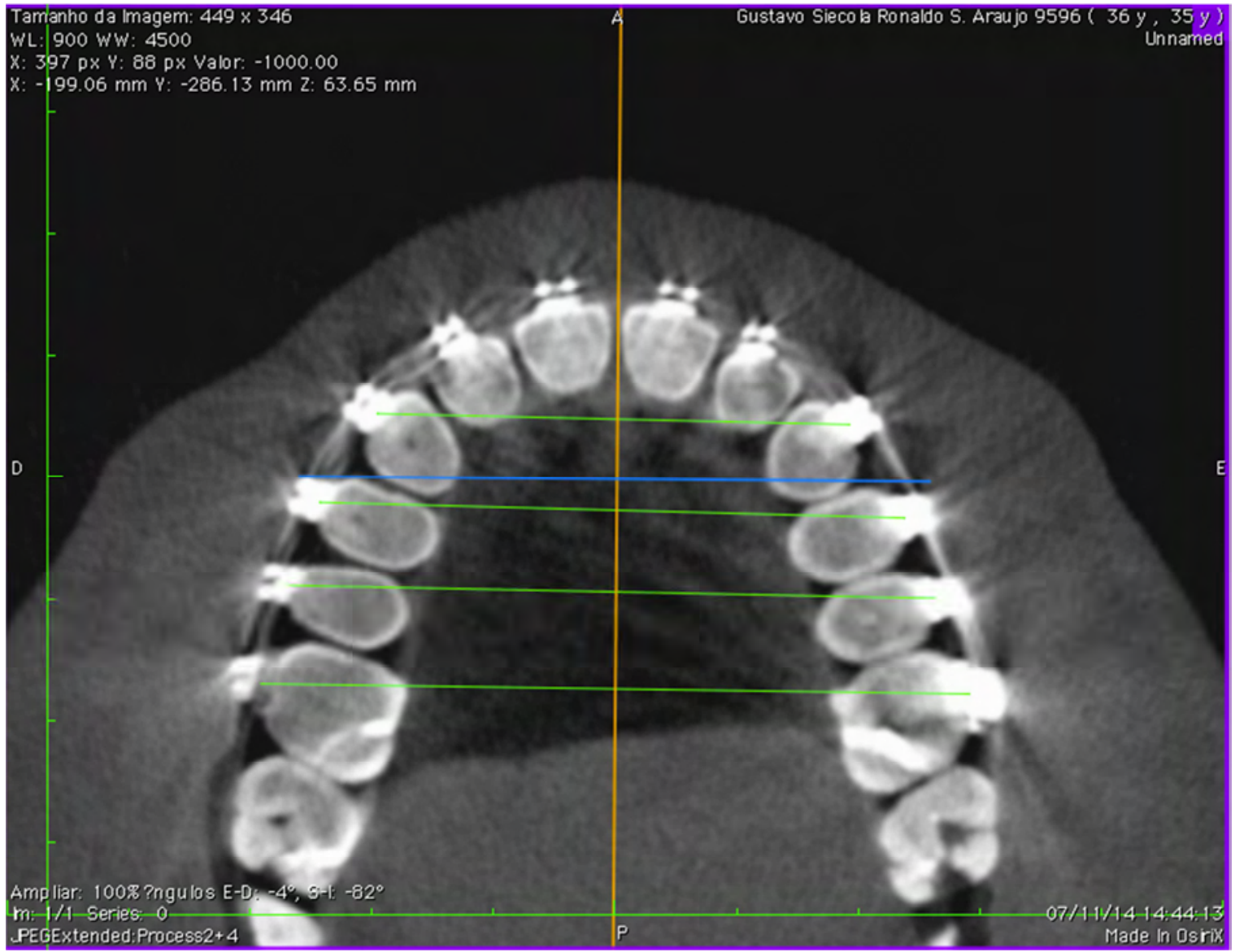

Figura 9 - Exemplo das medidas inter-dentárias 


\subsubsection{Método estatístico}

\subsubsection{Avaliação do erro do método}

As mensurações foram aferidas duas vezes, pelo mesmo operador, com intervalo de pelo menos um mês, em $30 \%$ da amostra. Foram calculados os erros casuais e sistemáticos respectivamente por meio da fórmula de Dahlberg, ME = $\left(\mathrm{Sd}^{2} / 2 \mathrm{n}\right)^{1 / 2}$, onde sd é a diferença entre as duas medidas e $\mathrm{n}$ é o numero de medidas executadas (Houston 1983).

\subsubsection{Análise estatística}

A normalidade dos dados foi verificada por meio do teste de KolmogorovSmirnov. Como os dados apresentaram uma distribuição normal, foram utilizados testes paramétricos.

Foi realizada a estatística descritiva das alterações dentoalveolares e de cristas ósseas em T1 e T2.

Para a comparação das variáveis estudadas entre as fases T1 e T2 foi utilizado o teste t dependente.

Os testes foram realizados com o programa Statistica (Statistica for Windows versão 7.0, Statsoft, Tulsa, Oklahoma, EUA). Foram considerados significantes valores de $\mathrm{P}<0,05$.

O cálculo amostral foi calculado baseado em um nível de significância alfa de $5 \%(0,05)$ e um beta de $20 \%(0,2)$ para atingir um poder de teste de $80 \%$ para detectar uma diferença média de $2,1^{\circ}$ com desvio padrão de $2,47^{\circ}$ para a angulação do primeiro molar (BAKA et al., 2015)

Desta forma, o cálculo amostral resultou que há necessidade de 13 indivíduos. 

5 Resultados 



\section{RESULTADOS}

\subsection{Erro sistemático e casual}

Houve erro sistemático em apenas 3 medidas das 32 totais destes trabalho, sendo elas a angulação dos molares $(p<0,017)$, angulação dos primeiros prémolares $(p<0,033)$ e distância da crista palatina ao plano palatino $(p<0,033)$. O erro casual variou de $0,04 \mathrm{~mm}$ a 0,40 graus. 
Tabela1 - Resultados do erro intra-examinador

\begin{tabular}{|c|c|c|c|c|c|c|}
\hline \multirow{2}{*}{ Variáveis } & \multicolumn{2}{|c|}{ T1 } & \multicolumn{2}{|c|}{ T2 } & \multirow{2}{*}{ Dahlberg } & \multirow{2}{*}{$\mathbf{P}$} \\
\hline & Média & d.p. & Média & d.p. & & \\
\hline CVM 6 & 24,46 & 1,31 & 24,48 & 1,36 & 0,07 & 0,762 \\
\hline RMV 6 & 25,79 & 2,07 & 25,76 & 2,01 & 0,05 & 0,350 \\
\hline ANG 6 & 92,12 & 2,24 & 92,51 & 2,36 & 0,36 & $0,017^{*}$ \\
\hline CRISTA V 6 & 27,06 & 2,06 & 27,09 & 2,16 & 0,19 & 0,818 \\
\hline CRISTA VV 6 & 16,96 & 2,94 & 16,95 & 2,97 & 0,07 & 0,762 \\
\hline CRISTA P 6 & 16,38 & 1,32 & 16,36 & 1,35 & 0,08 & 0,784 \\
\hline CRISTA PV 6 & 16,78 & 2,06 & 16,80 & 2,04 & 0,05 & 0,350 \\
\hline CVM 5 & 22,96 & 1,53 & 22,98 & 1,50 & 0,09 & 0,815 \\
\hline RMV 5 & 19,91 & 2,42 & 19,95 & 2,41 & 0,04 & 0,079 \\
\hline ANG 5 & 88,09 & 13,26 & 88,41 & 13,38 & 0,40 & 0,120 \\
\hline CRISTA V 5 & 24,81 & 1,78 & 24,79 & 1,82 & 0,08 & 0,598 \\
\hline CRISTA VV 5 & 17,45 & 2,90 & 17,46 & 2,89 & 0,04 & 0,598 \\
\hline CRISTA P 5 & 17,45 & 2,42 & 17,43 & 2,49 & 0,12 & 0,711 \\
\hline CRISTA PV 5 & 17,64 & 2,59 & 17,65 & 2,64 & 0,12 & 0,856 \\
\hline CVM 4 & 20,66 & 1,75 & 20,69 & 1,75 & 0,07 & 0,516 \\
\hline RMV 4 & 18,98 & 1,82 & 18,99 & 1,79 & 0,08 & 0,784 \\
\hline ANG 4 & 90,42 & 7,32 & 90,72 & 7,24 & 0,29 & $0,033^{*}$ \\
\hline CRISTA V 4 & 22,48 & 1,63 & 22,49 & 1,63 & 0,08 & 0,784 \\
\hline CRISTA VV 4 & 17,83 & 2,60 & 17,80 & 2,62 & 0,08 & 0,598 \\
\hline CRISTA P 4 & 13,35 & 1,61 & 13,36 & 1,63 & 0,09 & 0,815 \\
\hline CRISTA PV 4 & 17,39 & 2,35 & 17,40 & 2,40 & 0,09 & 0,801 \\
\hline CVM 3 & 17,55 & 2,18 & 17,56 & 2,18 & 0,04 & 0,598 \\
\hline RMV 3 & 15,28 & 1,85 & 15,30 & 1,87 & 0,05 & 0,350 \\
\hline ANG 3 & 95,89 & 6,23 & 96,15 & 6,22 & 0,34 & 0,142 \\
\hline CRISTA V 3 & 19,23 & 1,59 & 19,21 & 1,52 & 0,10 & 0,826 \\
\hline CRISTA VV 3 & 17,99 & 2,42 & 18,11 & 2,57 & 0,22 & 0,292 \\
\hline CRISTA P 3 & 11,89 & 1,39 & 11,96 & 1,26 & 0,13 & 0,301 \\
\hline CRISTA PV 3 & 19,64 & 3,22 & 19,94 & 3,24 & 0,30 & $0,033^{*}$ \\
\hline IC & 37,95 & 1,98 & 38,08 & 1,81 & 0,16 & 0,341 \\
\hline I1PM & 44,58 & 3,30 & 44,53 & 2,92 & 0,25 & 0,824 \\
\hline I2PM & 49,38 & 3,20 & 49,48 & 3,01 & 0,15 & 0,422 \\
\hline IM & 54,55 & 3,26 & 54,63 & 3,38 & 0,09 & 0,318 \\
\hline
\end{tabular}

* Estatisticamente significante para $\mathrm{P}<0,05$ 


\subsection{Resultados da amostra e medidas}

A amostra desta pesquisa foi composta por 13 indivíduos, sendo homens (6) e mulheres (7), estando todos já na vida adulta e portanto sem potencial de crescimento craniofacial, tendo como idade média inicial 29,23 anos e final, com 29,52 anos, como demonstrado na tabela 2.

Tabela 2 - Estatística descritiva das idades $(n=13)$

\begin{tabular}{c|c|c|c|c}
\hline Idade & Média & d.p. & Mínima & Máxima \\
\hline T1 & 29,23 & 9,13 & 18,42 & 51,50 \\
\hline T2 & 29,52 & 9,16 & 18,58 & 51,92 \\
\hline
\end{tabular}

Avaliando as alterações dentárias, as medidas com alterações significantes demonstram o aumento da distância entre a cúspide dos molares e o plano mediano vertical (CVM), o aumento do ângulo do longo eixo (ANG) bem como a movimentação vestibular (Crista V) e vertical (Crista VV) da crista óssea vestibular, com maior significância para as duas variáveis, conforme tabela 3. Houve uma diferença média de $1,33 \mathrm{~mm}$ por lado para este aumento da distância das cúspides ao plano mediano vertical, com alteração média angular de 4,16 graus.

Estas alterações dentárias também foram vistas para os segundos prémolares, apresentando aumentos significativos para CVM $(1,35 \mathrm{~mm})$, angulo $\left(5,27^{\circ}\right)$ e Crista V $(0,31 \mathrm{~mm})$, com diminuição do valor de RMV (ápice radicular ao plano mediano vertical $-0,37 \mathrm{~mm}$ ). (Tabela 4 )

Já para os primeiros pré-molares, as alterações significantes foram presentes em apenas CVM $(1,27 \mathrm{~mm})$ e ANG $\left(3,73^{\circ}\right)$. As demais medidas apresentaram alterações, porém sem significância estatística. (Tabela 5) 
Tabela 3 - Comparação das variáveis do primeiro molar entre as fases T1 e T2 (teste t dependente) $(n=26)$.

\begin{tabular}{c|c|c|c|c|c}
\hline \multirow{2}{*}{ Variáveis } & \multicolumn{2}{|c|}{ T1 } & \multicolumn{2}{c|}{ T2 } & \multirow{2}{*}{ P } \\
\cline { 2 - 5 } & Média & d.p. & Média & d.p. & \\
\hline CVM 6 & 24,90 & 1,50 & 26,23 & 1,67 & $\mathbf{0 , 0 0 0 ^ { * }}$ \\
\hline RMV 6 & 25,39 & 1,91 & 25,19 & 2,05 & 0,140 \\
\hline ANG 6 & 91,90 & 5,59 & 96,06 & 6,40 & $\mathbf{0 , 0 0 0 ^ { * }}$ \\
\hline CRISTA V 6 & 26,96 & 1,54 & 27,61 & 1,41 & $\mathbf{0 , 0 0 1 ^ { * }}$ \\
\hline CRISTA VV 6 & 17,37 & 2,96 & 16,80 & 3,31 & $\mathbf{0 , 0 3 8 ^ { * }}$ \\
\hline CRISTA P 6 & 16,39 & 1,17 & 16,67 & 1,15 & 0,143 \\
\hline CRISTA PV 6 & 17,66 & 2,73 & 17,67 & 3,20 & 0,965 \\
\hline
\end{tabular}

* Estatisticamente significante para $\mathrm{P}<0,05$

Tabela 4 - Comparação das variáveis do segundo pré-molar entre as fases T1 e T2 (teste t dependente) $(n=24)$.

\begin{tabular}{c|c|c|c|c|c}
\hline \multirow{2}{*}{ Variáveis } & \multicolumn{2}{|c|}{ T1 } & \multicolumn{2}{c|}{ T2 } & \multirow{2}{*}{ P } \\
\cline { 2 - 5 } & Média & d.p. & Média & d.p. & \\
\hline CVM 5 & 23,04 & 1,45 & 24,39 & 1,54 & $\mathbf{0 , 0 0 0 ^ { * }}$ \\
\hline RMV 5 & 19,67 & 1,86 & 19,30 & 1,81 & $\mathbf{0 , 0 3 1 ^ { * }}$ \\
\hline ANG 5 & 93,91 & 12,17 & 99,18 & 12,91 & $\mathbf{0 , 0 0 0 ^ { * }}$ \\
\hline CRISTA V 5 & 24,20 & 1,60 & 24,51 & 1,36 & $\mathbf{0 , 0 2 1 ^ { * }}$ \\
\hline CRISTA VV 5 & 17,90 & 2,62 & 17,65 & 2,66 & 0,367 \\
\hline CRISTA P 5 & 16,10 & 1,12 & 16,37 & 1,20 & 0,183 \\
\hline CRISTA PV 5 & 18,53 & 2,85 & 18,70 & 3,03 & 0,497 \\
\hline
\end{tabular}

* Estatisticamente significante para $\mathrm{P}<0,05$ 
Seguindo esta avaliação dentária por hemi-arco, os caninos apresentaram aumentos significantes estatisticamente para as variáveis CMV $(0,95 \mathrm{~mm})$ e $\operatorname{ANG}\left(1,93^{\circ}\right)$, tendo a RMV uma diminuição para o plano mediano vertical $(0,35 \mathrm{~mm})$, dados estes demonstrados na tabela 6.

Tabela 5 - Comparação das variáveis do primeiro pré-molar entre as fases T1 e T2 (teste t dependente) $(n=24)$.

\begin{tabular}{c|c|c|c|c|c}
\hline \multirow{2}{*}{ Variáveis } & \multicolumn{2}{|c|}{ T1 } & \multicolumn{2}{c}{ T2 } & \multirow{2}{*}{ P } \\
\cline { 2 - 5 } & Média & d.p. & Média & d.p. & \\
\hline CVM 4 & 20,77 & 1,63 & 21,90 & 1,60 & $0,000^{*}$ \\
\hline RMV 4 & 18,40 & 1,43 & 18,19 & 1,47 & 0,145 \\
\hline ANG 4 & 93,15 & 7,67 & 96,88 & 8,20 & $0,000^{*}$ \\
\hline CRISTA V 4 & 21,72 & 1,30 & 21,98 & 1,42 & 0,133 \\
\hline CRISTA VV 4 & 18,42 & 2,64 & 18,19 & 2,72 & 0,370 \\
\hline CRISTA P 4 & 13,48 & 1,21 & 13,88 & 1,59 & 0,084 \\
\hline CRISTA PV 4 & 18,87 & 2,89 & 18,86 & 2,80 & 0,975 \\
\hline
\end{tabular}

${ }^{*}$ Estatisticamente significante para $\mathrm{P}<0,05$

Tabela 6 - Comparação das variáveis do canino entre as fases T1 e T2 (teste t dependente) ( $n=26)$.

\begin{tabular}{c|c|c|c|c|c}
\hline \multirow{2}{*}{ Variáveis } & \multicolumn{2}{|c|}{ T1 } & \multicolumn{2}{c}{ T2 } & \multirow{2}{*}{ P } \\
\cline { 2 - 5 } & Média & d.p. & Média & d.p. & \\
\hline CVM 3 & 17,27 & 1,51 & 17,92 & 1,66 & $\mathbf{0 , 0 0 2}^{*}$ \\
\hline RMV 3 & 14,15 & 1,66 & 13,80 & 1,45 & $\mathbf{0 , 0 0 3 ^ { * }}$ \\
\hline ANG 3 & 98,28 & 5,21 & 100,21 & 5,66 & $\mathbf{0 , 0 0 0 *}$ \\
\hline CRISTA V 3 & 18,36 & 1,49 & 18,57 & 1,40 & 0,188 \\
\hline CRISTA VV 3 & 18,41 & 2,55 & 18,07 & 2,42 & 0,289 \\
\hline CRISTA P 3 & 11,38 & 1,03 & 11,64 & 1,02 & 0,099 \\
\hline CRISTA PV 3 & 19,05 & 2,13 & 19,35 & 2,25 & 0,095 \\
\hline
\end{tabular}

* Estatisticamente significante para $\mathrm{P}<0,05$ 
Seguindo para as medidas inter-dentárias, houve aumento significante em todas as distâncias, entre os caninos $(0,70 \mathrm{~mm})$, entre os $1^{\circ}$ pré-molares $(2,12 \mathrm{~mm})$, entre os $2^{\circ}$ pré-molares $(2,49 \mathrm{~mm})$ e entre os $1^{\circ}$ molares $(2,40 \mathrm{~mm})$. (Tabela 7$)$

Tabela 7 - Comparação das distâncias inter-dentárias entre as fases T1 e T2 (teste t dependente) $(n=13)$.

\begin{tabular}{c|c|c|c|c|c}
\hline \multirow{2}{*}{ Variáveis } & \multicolumn{2}{|c|}{ T1 } & \multicolumn{2}{c|}{ T2 } & \multirow{2}{*}{ P } \\
\cline { 2 - 5 } & Média & d.p. & Média & d.p. & \\
\hline I-C & 37,39 & 2,10 & 38,10 & 1,95 & $\mathbf{0 , 0 0 0 ^ { * }}$ \\
\hline I-1 $^{\circ} \mathrm{PM}$ & 44,48 & 2,61 & 46,60 & 2,11 & $\mathbf{0 , 0 0 0 ^ { * }}$ \\
\hline I-2 $^{\circ} \mathrm{PM}$ & 49,22 & 2,50 & 51,71 & 2,41 & $\mathbf{0 , 0 0 0 ^ { * }}$ \\
\hline I-M & 54,59 & 2,76 & 56,99 & 2,60 & $\mathbf{0 , 0 0 1 ^ { * }}$ \\
\hline
\end{tabular}

* Estatisticamente significante para $\mathrm{P}<0,05$ 
6 DIscussÃo 



\section{DISCUSSÃO}

\subsection{Material e metodologia}

Depois de execução do estudo piloto para verificar a amplitude de alterações de angulação dos molares, medida escolhida para referência e com no desvio padrão para a mesma medida angular na literatura, o cálculo amostral determinou o $n$ de 13 pacientes (BAKA et al., 2015). Amostra deste trabalho foi composta por indivíduos já adultos, portanto sem potencial de crescimento craniofacial. Foi composta por 6 homens e 7 mulheres, com idade média de 29,23 anos no início do tratamento. Dentre os pacientes desta amostra, apenas 1 mulher apresentava mordida cruzada posterior dentária, comprometendo apenas o dente 26 ( $1^{\circ}$ molar permanente superior esquerdo). Todos os demais pacientes apresentavam atresia maxilar dentária, com grande expressão de corredor bucal, com visível inclinação lingual dos dentes posteriores e com grau leve a moderado de apinhamento ânterosuperior.

O erro casual e o erro sistemático deste trabalho foram considerados aceitáveis, uma vez que apenas 3 de 32 medidas realizadas apresentaram erros sistemáticos, sendo elas as angulares de primeiro molares e primeiro pré-molares, alem da medida da crista palatina no sentido vertical (ao plano palatino) do canino. Já o erro casual também apresentou uma pequena variação, sendo de 0,04 mm nas medidas RMV5, CRISTAVV5 e CVM3 até 0,40 graus para angulação do segundo pré-molar.

Diversos são os trabalhos atuais contemplando as tomografias computadorizadas, especialmente do tipo cone-beam, com o intuito de completar e elucidar as alterações durante o crescimento craniofacial (ARANA-FERNANDEZ DE MOYA et al., 2006, BISHARA, 2000, GARIB et al., 2014a, KABALAN et al., 2015, SANDERS et al., 2010), as características esqueléticas de cada tipo facial (ANDRUCH; PLACHTA, 2015, GARIB et al., 2014b, JOHARI; KAVIANI; SAEEDI, 2015, OZDEMIR; TOZLU; GERMEC-CAKAN, 2013), bem como os diagnósticos e limites terapêuticos dentro da ortodontia (AKIN et al., 2016, AKIN et al., 2014, BAKA et al., 2015, BALLANTI et al., 2010, BARATIERI et al., 2011, CAPPS et al., 2015, 
CORBRIDGE et al., 2011, GARIB et al., 2007a, GARIB et al., 2006, GARIB et al., 2005, GARIB et al., 2014b).

A tomografia computadorizada é um exame tridimensional, o que traz uma percepção muito mais ampla do diagnóstico. Torna-se possível determinar o real problema, determinar com precisão o tipo de atuação bem como identificar as limitações individuais. Exatamente por esta capacidade de exame, que existe a necessidade de padronização das tomografias obtidas, principalmente no que tange a posição de cabeça. É possível que esta padronização aconteça já durante a obtenção do exame (CAPPS et al., 2015, GARIB et al., 2006, GARIB et al., 2005), ou após pela alterações das imagens no próprio programa de interpretação (AKIN et al., 2016, AKIN et al., 2014, BAKA et al., 2015, BAYSAL et al., 2013, JOHARI; KAVIANI; SAEEDI, 2015).

Este estudo realizou a padronização inicial da tomografia já durante a realização do exame, utilizando o plano de Frankfurt como referência. No entanto, como este trabalho também contemplou medidas lineares e angulares, realizadas a partir de pontos determinados de elementos dentários e estruturas ósseas até um plano vertical mediano, também criado no programa de avaliação, houve a necessidade de padronização mais detalhada ajustando os exames e planos (AKIN et al., 2014, BAKA et al., 2015). Como o intuito deste trabalho não foi alterações ortopédicas, pode-se utilizar o plano palatino como referência principal. Com o exame detalhado em visões multiplanares, o plano axial foi determinando passando pela espinha nasal anterior e espinha nasal posterior. Ajustando o giro horizontal da cabeça do paciente, no corte axial, o plano sagital foi determinado passando em $90^{\circ}$ com o plano anterior. Já para a correção de giro vertical da posição da cabeça do paciente, a imagem foi ajustada deixando o plano axial paralelo ao plano palatino na região de $2^{\circ}$ molares permanentes, onde existe uma continuidade mais estreita do palato, formando uma linha (CORBRIDGE et al., 2011). Assim, o exame ficou padronizado nos três plano, com o exame pré e pós do paciente ajustado de mesma maneira para que as medidas fossem fidedignas.

Uma vez padronizado, as medidas foram realizadas de maneira bilateral, seguindo o estudo com a metodologia empregada neste trabalho (BAKA et al., 2015). No entanto, diferentemente do trabalho citado, onde havia a necessidade de 
investigar os efeito de cada quadrante, por se tratar de uma mecânica assimétrica, este presente estudo avaliou sem a distinção por quadrante, uma vez que a força de expansão empregada pelo arco auxiliar foi recíproca, sem qualquer tipo de ancoragem diferente entre os quadrantes. Ainda, os critérios de inclusão não contemplavam a necessidade de diagnóstico de atresia assimétrica.

Quanto a medida de angulação, optou-se pela utilização dos pontos de referência as cúspides vestibulares e os ápices radiculares vestibulares (quando pertinente) pela facilidade de medição, pois estes pontos já foram utilizados para medidas lineares. Isso difere do artigo de Baka et al por terem sidos utilizadas as cúspides palatinas e ápices radiculares palatinos (quando pertinente) (BAKA et al., 2015).

A opção de utilização dos filtros do próprio programa, sendo o flow e perfusion, teve por objetivo a facilitação de detecção dos limites ósseos, principalmente, pois nos exames em escala de cinza (sem filtros) foi encontrada dificuldade para delimitação. Estas medidas das cristas ósseas vestibular e palatina foi realizada na imagem onde havia maior continuidade da raiz, com maior luz do canal endodôntico, de maneira a padronizar.

\subsection{Efeitos dentoalveolares}

Esta técnica de expansão com arco auxiliar em TMA e em pacientes adultos demonstrou resultados significativos de aumento das medidas de ponta de cúspide ao plano vertical mediano, em todos os elementos dentários medidos, sendo maios significativos de $1^{\circ}$ pré-molar para posterior, embora ara caninos a significância do aumento também tenha relevância estatística. Estas alterações serem maiores nos dentes posteriores é compreensível pelo próprio desenho do aparelho, que com o arco auxiliar traciona o fio de nivelamento de maneira a expandí-lo, promovendo um maior braço de alavanca na região posterior. Este fato também se explica por ser a área de maior união do arco auxiliar ao fio de nivelamento ser exatamente na entrada dos tubos dos molares e na região entre os bráquetes do pré-molares, com amarrilhos. Prevendo esta possível alteração, este amarrilho foi sempre instalado de forma a não pressionar mais a área dos pré-molares a ponto de perder o contato do 
helicoide do arco auxiliar do fio de nivelamento na entrada do tudo dos molares, com a intensão de manter a força homogênea e igualmente distribuída pelo fio principal.

Esta alteração na região de caninos teve como distância média de ponta de cúspide e o plano vertical mediano (PVM) em T1 17,27mm e em T2, 17,92mm, com variação pequena de $0,65 \mathrm{~mm}$, sendo ainda sim significante. Este ganho desta distancia está associada a inclinação vestibular, com aumento também na medida angular, que apresentava em T1 $98,28^{\circ}$ e em T2 $100,21^{\circ}$, com variação de $1,93^{\circ}$. Não houve para os caninos significância nas demais medidas, sem grandes movimentos de ápice radicular para palatino, como foi apresentado nos demais dentes. Rossi et al descreveu um valor maior em torno de $4,5 \mathrm{~mm}$, também no protocolo de expansão lenta e portanto sem romper sutura palatina (ROSSI; ARAÚJO; BOLOGNESE, 2009). No entanto, este valor é ligeiramente maior que o descrito por Pinheiro et al, onde em seu trabalho não houve alteração significante na região dos caninos, mesmo sendo realizado expansão lenta utilizando 2 grupos com expansores fixos e um grupo com controle e aparelho edgewise (PINHEIRO et al., 2014).

Seguindo para os dentes posteriores, estes aumentos das distância entre as pontas de cúspides e o plano vertical mediano se tornaram mais expressivos, sendo de $1,13 \mathrm{~mm}$ para $1^{\circ}$ pré-molares, $1,35 \mathrm{~mm}$ para $2^{\circ}$ pré-molares e $1,31 \mathrm{~mm}$ para $1^{\circ}$ molares permanentes. As movimentação dos ápices radiculares para mais próximo do plano vertical mediano foi de $0,21 \mathrm{~mm}, 0,37 \mathrm{~mm}$ e $0,20 \mathrm{~mm}$, respectivamente, sendo significante apenas para os $2^{\circ}$ pré-molares. Estes valores de aumento das distância das cúspides ao PVM são menores que os descritos por Baka et al, que apresentou $3,58 \mathrm{~mm}$ para $1^{\circ} \mathrm{PM}, 2,86 \mathrm{~mm}$ para $2^{\circ} \mathrm{PM}$ e $2,15 \mathrm{~mm}$ para $1^{\circ} \mathrm{M}$. Esta diferença é explicada pelo fato de no trabalho de Baka et al ter ocorrido ruptura da sutura palatina mediana e, portanto, com incrementos em distância também ligados ao efeito ortopédico (BAKA et al., 2015).

Para explicar esta maior movimentação das pontas de cúspides e menores dos ápices radiculares existe a alteração angular presente para estes dentes, tendo aumento estatisticamente significante para todos os dentes posteriores, sendo de $3,73^{\circ}$ para $1^{\circ}$ pré-molares, $5,27^{\circ}$ para $2^{\circ}$ pré-molares e de $4,16^{\circ}$ para $1^{\circ}$ molares. Estes valores de inclinação dos molares são próximos aos encontrados na literatura, 
sendo compatível com a vestibularização de $4^{\circ}$ descrita por Rossi et al (2009), e estando ligeiramente maior ao descrito por Capelozza et al (1996) e por Handelman et al (2000), que encontrou 3,10 de vestibularização dos molares. As inclinações vestibulares deste trabalho também estão similares às descritas por Baka et al (2015), com exceção dos $1^{\circ}$ pré-molares que foi descrita com valores maiores, $5,79^{\circ}$, enquanto que para $2^{\circ}$ pré-molares e $1^{\circ}$ molares os valores foram $5,45^{\circ}$ e $4,46^{\circ}$, respectivamente. Este aumento de inclinação vestibular está associada ao desenho deste estudo, uma vez que o fio de nivelamento utilizado foi um 0,017x0,025" de níquel-titânio termoativado, o que gera folga significativa entre o fio e o slot da prescrição utilizada $(0,022 \times 0,028$ "). Este aumento de inclinação ser maior na área de $1^{\circ}$ molares e $2^{\circ}$ pré-molares e decrescente em magnitude para a região de caninos também se explica pelo desenho do aparelho, uma vez que o arco auxiliar de expansão tem sua área de união com o fio de nivelamento exatamente na mesial dos tubos dos molares e entre os bráquetes dos pré-molares, além do fato que o arco auxiliar ser inicialmente confeccionado sem diagramação, ou seja, retificado, apenas com um helicoide em cada extremidade. Assim, a dissipação de força pode ser esperada maior quanto mais na extremidade do fio estiver a união.

Quando analisada as alterações em crista óssea alveolar, este presente trabalho apresentou movimentação da crista óssea vestibular com aumento da distância em relação ao PVM de maneira significante apenas para $2^{\circ}$ pré-molares e $1^{\circ}$ molares, sendo $0,31 \mathrm{~mm}$ e $0,65 \mathrm{~mm}$, em média, respectivamente. No sentido vertical, apenas a crista óssea vestibular dos $1^{\circ}$ molares apresentaram alterações significativas, sendo uma diminuição da altura em $0,57 \mathrm{~mm}$. Este achado acompanha os descritos na literatura que apontam alguma deflexão do processo alveolar no sentido da movimentação, em torno de $4^{\circ}$ (HANDELMAN et al., 2000). Esta magnitude de alteração da crista óssea alveolar vestibular não é a mesma da quantidade de aumento da distância entre a ponta de cúspide dos dentes posteriores e o PVM, sendo estas últimas maiores. Isso se explica pelo fato de este aumento linear estar associado ao aumento da inclinação vestibular, e portanto com pequeno ou nenhum movimento de corpo, além do fato de já ter sido descrito a possibilidade de movimento dentário dentro do osso alveolar (CORBRIDGE et al., 2011). 
Analisando os ganhos transversais totais deste trabalho, foram realizadas as medições das distâncias inter-caninos, inter-pré-molares e inter-molares. A distância inter-caninos teve aumento médio de $37,39 \mathrm{~mm}$ para $38,10 \mathrm{~mm}(0,71 \mathrm{~mm})$, na região dos $1^{\circ}$ pré-molares de $44,48 \mathrm{~mm}$ para $46,60 \mathrm{~mm}(2,12 \mathrm{~mm})$, na de $2^{\circ}$ pré-molares de $49,22 \mathrm{~mm}$ para $51,71 \mathrm{~mm}(2,49 \mathrm{~mm})$ e na de $1^{\circ}$ molares de $54,59 \mathrm{~mm}$ para $56,99 \mathrm{~mm}$ $(2,40 \mathrm{~mm})$. Os aumentos reais deste trabalho estiveram abaixo da média descrita e pesquisada na literatura (CORBRIDGE et al., 2011, HANDELMAN et al., 2000, RIBEIRO et al., 2006, ROSSI; ARAÚJO; BOLOGNESE, 2009). Isso se explica por duas variáveis destes artigos, sendo elas a amostra ser compreendida de crianças, e portanto contar também com o crescimento craniofacial e pelo fato de objetivos de expansão rápida da maxila, com ruptura de sutura palatina mediana, como descrito. Em comparação a outros estudos, este aumento inter-molares se demonstrou semelhantes, com magnitudes próximas (CAPELOZZA FILHO et al., 1996, LIMA FILHO; RUELLAS, 2008, MACHADO JUNIOR; CRESPO, 2006, MARTINA et al., 2012). A justificativa para esta concordância está no fato destes artigos contemplarem avaliações de expansão lenta de maxila, ou por meio de arco extrabucal aberto, ou arcos de nivelamento com diagramação maior ou mesmo com aparelhos fixos tipo quadrihélice, além de alguns deles estudarem em amostra de pacientes adultos, como neste presente estudo. Sendo assim, os efeitos estão limitados as compensações dentoalveolares, com inclinações dentárias, pequenos movimentos dentro do processo alveolar e pequenas remodelações de crista ósseas, principalmente por vestibular.

Embora não se acredite haver diferença entre os ganhos transversais reais, por se tratar de alterações proporcionais entre o mesmo indivíduo em dois tempos distintos, este trabalho diferentemente da literatura amplamente descrita, não realizou as medidas inter-dentárias a partir da ponta de cúspide, e sim a distância inter-acessórios ortodônticos de seu respectivo dente avaliado. Esta escolha ocorreu devido a distorções causadas pela presença de restaurações metálicas em alguns pacientes, promovendo uma perda significativa de nitidez e dificultando a exata localização da ponta de cúspide, promovendo erros de medidas (ARANAFERNANDEZ DE MOYA et al., 2006). 
7 CONCLUSÃO 



\section{CONCLUSÃO}

O presente trabalho obteve as respostas propostas pelo seu objetivo. Os ganhos transversais encontrados foram condizentes em magnitude com os descritos na literatura com amostra e metodologia compatíveis. Os efeitos dentários foram o aumento das distâncias inter-dentárias, sendo menor na região dos caninos e maiores nas regiões de $2 \square$ pré-molares e $1 \square$ molares. Estes aumentos transversais foram obtidos por pequenos movimentos de translação dentária dentro do processo alveolar, associado com o aumento da inclinação vestibular dos dentes de suporte, especialmente os $1 \square$ molares e $2 \square$ pré-molares. As cristas ósseas alveolares vestibulares acompanharam o movimento transversal, porém em menor magnitude do que a movimentação dentária 



\section{REFERÊNCIAS}





\section{REFERÊNCIAS}

Akin M, Akgul YE, Ileri Z, Basciftci FA. Three-Dimensional Evaluation of Hybrid Expander Appliances: A Pilot Study. Angle Orthod. 2016 Jan;86(1):81-6.

Akin M, Baka ZM, Ileri Z, Basciftci FA. Alveolar Bone Changes after Asymmetric Rapid Maxillary Expansion. Angle Orthod. 2014 Dec 5;

Andrews LF. The Six Keys to Normal Occlusion. Am J Orthod. 1972 Sep;62(3):296309.

Andruch K, Plachta A. Evaluating Maxilla Bone Quality through Clinical Investigation of Voxel Grey Scale Values from Cone-Beam Computed Tomography for Dental Use. Adv Clin Exp Med. 2015 Nov-Dec;24(6):1071-7.

Angle EH. Malocclusion of the Teeth: Philadelphia: S. S. White Dental Mfg. Co.; 1907.

Arana-Fernandez de Moya E, Buitrago-Vera P, Benet-Iranzo F, Tobarra-Pérez E. Tomografía Computerizada: IntroduccióN a Las Aplicaciones Dentales. RCOE. 2006 11(3):11.

Baka ZM, Akin M, Ucar FI, lleri Z. Cone-Beam Computed Tomography Evaluation of Dentoskeletal Changes after Asymmetric Rapid Maxillary Expansion. Am J Orthod Dentofacial Orthop. 2015 Jan;147(1):61-71.

Ballanti F, Lione R, Baccetti T, Franchi L, Cozza P. Treatment and Posttreatment Skeletal Effects of Rapid Maxillary Expansion Investigated with Low-Dose Computed Tomography in Growing Subjects. Am J Orthod Dentofacial Orthop. 2010 Sep;138(3):311-7.

Baratieri C, Alves M, Jr., Sant'anna EF, Nojima Mda C, Nojima LI. 3d Mandibular Positioning after Rapid Maxillary Expansion in Class li Malocclusion. Braz Dent J. 2011 22(5):428-34.

Baratieri Cda L, Alves M, Jr., Mattos CT, Lau GW, Nojima LI, Souza MM. Transverse Effects on the Nasomaxillary Complex One Year after Rapid Maxillary Expansion as the Only Intervention: A Controlled Study. Dental Press J Orthod. 2014 SepOct;19(5):79-87. 
Barbosa JS. Acurácia De Medidas Lineares Em Softwares De Planejamento De Implantes Sobre Imagens De Mandibulas Atróficas Obtidas Por Tomografias Computadorizadas De Feixe Cônico Com Diferentes Protocolos De Aquisição. São Paulo: Faculdade de Odontologia; 2014.

Baysal A, Uysal T, Veli I, Ozer T, Karadede I, Hekimoglu S. Evaluation of Alveolar Bone Loss Following Rapid Maxillary Expansion Using Cone-Beam Computed Tomography. Korean J Orthod. 2013 Apr;43(2):83-95.

Bechara FG, Bigliazzi R, Chelotti A, Barbosa HAM, Ladislau AS, Faltin Junior K. AvaliaçãO Das DimensõEs Transversas Na Maxila E MandíBula Em Pacientes Na Fase Da DentiçãO Mista Tratados Com Aparelho OrtodôNtico RemovíVel Superior. Pesq Bras Odontoped Clin Integr. 2010 maio/ago;10(2):6.

Bell WH, Epker BN. Surgical-Orthodontic Expansion of the Maxilla. Am J Orthod. 1976 Nov;70(5):517-28.

Betts NJ, Vanarsdall RL, Barber HD, Higgins-Barber K, Fonseca RJ. Diagnosis and Treatment of Transverse Maxillary Deficiency. Int J Adult Orthodon Orthognath Surg. 1995 10(2):75-96.

Bishara SE. Facial and Dental Changes in Adolescents and Their Clinical Implications. Angle Orthod. 2000 Dec;70(6):471-83.

Brunetto M, Andriani Jda S, Ribeiro GL, Locks A, Correa M, Correa LR. ThreeDimensional Assessment of Buccal Alveolar Bone after Rapid and Slow Maxillary Expansion: A Clinical Trial Study. Am J Orthod Dentofacial Orthop. 2013 May;143(5):633-44.

Capelozza Filho L, Cardoso Neto J, da Silva Filho OG, Ursi WJ. Non-Surgically Assisted Rapid Maxillary Expansion in Adults. Int J Adult Orthodon Orthognath Surg. 1996 11(1):57-66; discussion 7-70.

Capps CJ, Campbell PM, Benson B, Buschang PH. Can Posterior Teeth of Patients Be Translated Buccally, and Does Bone Form on the Buccal Surface in Response? Angle Orthod. 2015 Dec 14;

Cardoso Mde A, Guedes FP, Paranhos LR, Garib DG, Capelozza Filho L. Preventive Orthodontic Management of Tooth Transposition. Int J Orthod Milwaukee. 2014 Winter;25(4):45-50. 
Chen C-H, Nakano H, Liou EJW, Maki K. A Cone Beam Computer Tomographic Study of the Cortical Bone Thickness in Different Class li Facial Patterns. Orthodontic Waves. 2010 69(6.

Corbridge JK, Campbell PM, Taylor R, Ceen RF, Buschang PH. Transverse Dentoalveolar Changes after Slow Maxillary Expansion. Am J Orthod Dentofacial Orthop. 2011 Sep;140(3):317-25.

D'Souza IM, Kumar HC, Shetty KS. Dental Arch Changes Associated with Rapid Maxillary Expansion: A Retrospective Model Analysis Study. Contemp Clin Dent. 2015 Jan-Mar;6(1):51-7.

Fish LC, Epker BN. Prevention of Relapse in Surgical-Orthodontic Treatment. Part 1. Mandibular Procedures. J Clin Orthod. 1986 Dec;20(12):826-41.

Fuhrmann RAW. Three-Dimensional Evaluation of Periodontal Remodeling During Orthodontic Treatment. Semin Orthod. 2002 8(1):5.

Garib DG, Calil LR, Leal CR, Janson G. Is There a Consensus for Cbct Use in Orthodontics? Dental Press J Orthod. 2014a Sep-Oct;19(5):136-49.

Garib DG, Henriques JF, Carvalho PE, Gomes SC. Longitudinal Effects of Rapid Maxillary Expansion. Angle Orthod. 2007a May;77(3):442-8.

Garib DG, Henriques JF, Janson G, de Freitas MR, Fernandes AY. Periodontal Effects of Rapid Maxillary Expansion with Tooth-Tissue-Borne and Tooth-Borne Expanders: A Computed Tomography Evaluation. Am J Orthod Dentofacial Orthop. 2006 Jun;129(6):749-58.

Garib DG, Henriques JF, Janson G, Freitas MR, Coelho RA. Rapid Maxillary Expansion--Tooth Tissue-Borne Versus Tooth-Borne Expanders: A Computed Tomography Evaluation of Dentoskeletal Effects. Angle Orthod. 2005 Jul;75(4):54857.

Garib DG, Menezes MH, Silva Filho OG, Santos PB. Immediate Periodontal Bone Plate Changes Induced by Rapid Maxillary Expansion in the Early Mixed Dentition: Ct Findings. Dental Press J Orthod. 2014b May-Jun;19(3):36-43.

Garib DG, R. RJ, Raymundo MV, Raymundo DV, Ferreira SN. Tomografia Computadorizada De Feixe CôNico (Cone Beam): Entendendo Este Novo MéTodo De DiagnóStico Por Imagem Com Promissora Aplicabilidade Na Ortodontia. $\mathrm{R}$ Dental Press Ortodon Ortop Facial. 2007b mar/abr;12(2):17. 
Garib DG, Yatabe MS, Ozawa TO, Filho OG. Alveolar Bone Morphology in Patients with Bilateral Complete Cleft Lip and Palate in the Mixed Dentition: Cone Beam Computed Tomography Evaluation. Cleft Palate Craniofac J. 2012 Mar;49(2):208-14.

Gravina MA, Brunharo IH, Fraga MR, Artese F, Campos MJ, Vitral RW, et al. Clinical Evaluation of Dental Alignment and Leveling with Three Different Types of Orthodontic Wires. Dental Press J Orthod. 2013 Nov-Dec;18(6):31-7.

Haas AJ. The Treatment of Maxillary Deficiency by Opening the Midpalatal Suture. Angle Orthod. 1965 Jul;35(200-17.

Haas AJ. Palatal Expansion: Just the Beginning of Dentofacial Orthopedics. Am J Orthod. 1970 Mar;57(3):219-55.

Haas AJ. Long-Term Posttreatment Evaluation of Rapid Palatal Expansion. Angle Orthod. 1980 Jul;50(3):189-217.

Haas AJ. Entrevista. R Dental Press Ortodon Ortop Facial. 2001 Jan/Fev;6(1):10.

Handelman CS. Nonsurgical Rapid Maxillary Alveolar Expansion in Adults: A Clinical Evaluation. Angle Orthod. 1997 67(4):291-305; discussion 6-8.

Handelman CS, Wang L, BeGole EA, Haas AJ. Nonsurgical Rapid Maxillary Expansion in Adults: Report on 47 Cases Using the Haas Expander. Angle Orthod. 2000 Apr;70(2):129-44.

Huynh T, Kennedy DB, Joondeph DR, Bollen AM. Treatment Response and Stability of Slow Maxillary Expansion Using Haas, Hyrax, and Quad-Helix Appliances: A Retrospective Study. Am J Orthod Dentofacial Orthop. 2009 Sep;136(3):331-9.

Iseri H, Ozsoy S. Semirapid Maxillary Expansion--a Study of Long-Term Transverse Effects in Older Adolescents and Adults. Angle Orthod. 2004 Feb;74(1):71-8.

Johari M, Kaviani F, Saeedi A. Relationship between the Thickness of Cortical Bone at Maxillary Mid-Palatal Area and Facial Height Using Cbct. Open Dent J. 2015 9(287-91.

Junqueira $\mathrm{CH}$, Janson G, Junqueira MH, Mendes LM, Favilla EE, Garib DG. Comparison between Full Face and Hemifacial Cbct Cephalograms in Clinically Symmetrical Patients: A Pilot Study. Dental Press J Orthod. 2015 Mar-Apr;20(2):839. 
Kabalan O, Gordon J, Heo G, Lagravere MO. Nasal Airway Changes in Bone-Borne and Tooth-Borne Rapid Maxillary Expansion Treatments. Int Orthod. 2015 Mar;13(1):1-15.

Lee RJ, Weissheimer A, Pham J, Go L, de Menezes LM, Redmond WR, et al. ThreeDimensional Monitoring of Root Movement During Orthodontic Treatment. Am J Orthod Dentofacial Orthop. 2015 Jan;147(1):132-42.

Lima AL, Lima Filho RM, Bolognese AM. Long-Term Clinical Outcome of Rapid Maxillary Expansion as the Only Treatment Performed in Class I Malocclusion. Angle Orthod. 2005 May;75(3):416-20.

Lima Filho RM, Ruellas AC. Long-Term Maxillary Changes in Patients with Skeletal Class li Malocclusion Treated with Slow and Rapid Palatal Expansion. Am J Orthod Dentofacial Orthop. 2008 Sep;134(3):5.

Linder-Aronson S, Lindgren J. The Skeletal and Dental Effects of Rapid Maxillary Expansion. Br J Orthod. 1979 Jan;6(1):25-9.

Lindner A. Longitudinal Study on the Effect of Early Interceptive Treatment in 4-YearOld Children with Unilateral Cross-Bite. Scand J Dent Res. 1989 Oct;97(5):432-8.

Lorenzoni DC, Bolognese AM, Garib DG, Guedes FR, Sant'anna EF. Cone-Beam Computed Tomography and Radiographs in Dentistry: Aspects Related to Radiation Dose. Int J Dent. 2012 2012(813768.

Machado Junior AJ, Crespo AN. Cephalometric Study of Alterations Induced by Maxillary Slow Expansion in Adults. Braz J Otorhinolaryngol. 2006 MarApr;72(2):166-72.

Martina R, Cioffi I, Farella M, Leone P, Manzo P, Matarese G, et al. Transverse Changes Determined by Rapid and Slow Maxillary Expansion--a Low-Dose Ct-Based Randomized Controlled Trial. Orthod Craniofac Res. 2012 Aug;15(3):159-68.

McNamara JA. Maxillary Transverse Deficiency. Am J Orthod Dentofacial Orthop. 2000 May;117(5):567-70.

O'Dywer L, Littlewood SJ, Rahman S, Spencer RJ, Barber SK, Russell JS. A MultiCenter Randomized Controlled Trial to Compare a Self-Ligating Bracket with a Conventional Bracket in a Uk Population: Part 1: Treatment Efficiency. Angle Orthod. 2016 Jan;86(1):142-8. 
Ozdemir F, Tozlu M, Germec-Cakan D. Cortical Bone Thickness of the Alveolar Process Measured with Cone-Beam Computed Tomography in Patients with Different Facial Types. Am J Orthod Dentofacial Orthop. 2013 Feb;143(2):190-6.

Pinheiro FH, Garib DG, Janson G, Bombonatti R, de Freitas MR. Longitudinal Stability of Rapid and Slow Maxillary Expansion. Dental Press J Orthod. 2014 NovDec;19(6):70-7.

Prado E. Questionando Paradigmas No Tratamento Da Classe lii Em Adultos. Qual Seria O Limite Da CompensaçãO Em Pacientes Adultos? Existe Remodelação Dentoalveolar Ou O Problema Esquelético Ou a Seria Uma Maldição? Rev Clín Ortodon Dental Press. 2007 6(3):16-29.

Proffit WR. The Soft Tissue Paradigm in Orthodontic Diagnosis and Treatment Planning: A New View for a New Century. J Esthet Dent. 2000 12(1):46-9.

Quintao CC, Cal-Neto JP, Menezes LM, Elias CN. Force-Deflection Properties of Initial Orthodontic Archwires. World J Orthod. 2009 Spring;10(1):29-32.

Raposo AK, de Carvalho EF, Souto MF, Garib DG, Seabra FR, Pinheiro FH. Is Lower Incisor Inclination a Good Parameter to Estimate Alveolar Bone Level? A Cone-Beam Ct Evaluation. Int J Orthod Milwaukee. 2011 Winter;22(4):33-9.

Ribeiro GLU, Vieira GdL, Ritter D, Tanaka OM, Weissheimer A. ExpansãO Maxilar RáPida NãO CirúRgica Em Paciente Adulto. Uma Alternativa PossíVel. Rev Clín Ortodon Dental Press. 2006 abr/maio;5(2):7.

Rossi RRP, Araújo MnTrd, Bolognese AM. ExpansãO Maxilar Em Adultos E Adolescentes Com MaturaçãO EsqueléTica AvançAda. R Dental Press Ortodon Ortop Facial. 2009 set/out;14(5):9.

Sanders DA, Rigali PH, Neace WP, Uribe F, Nanda R. Skeletal and Dental Asymmetries in Class li Subdivision Malocclusions Using Cone-Beam Computed Tomography. Am J Orthod Dentofacial Orthop. 2010 Nov;138(5):542 e1-20; discussion -3 .

Silva Filho OGd, Pinheiro Júnior JMs, Cavassan AdO. Comportamento Dos Incisivos Centrais Superiores ApóS a ExpansãO RáPida Da Maxila Na Dentadura Mista: Um Estudo Piloto Longitudinal RadiográFico. Revista Dental Press de Ortodontia e Ortopedia Maxilar. 1997 2(1):17. 
Thilander B, Myrberg N. The Prevalence of Malocclusion in Swedish Schoolchildren. Scand J Dent Res. 1973 81(1):12-21.

Tweed $\mathrm{CH}$. Indications for the Extraction of Teeth in Orthodontic Procedure. Am J Orthod Oral Surg. 1944 42(22-45.

Urbaniak JA, Brantley WA, Pruhs RJ, Zussman RL, Post AC. Effects of Appliance Size, Arch Wire Diameter, and Alloy Composition on the in Vitro Force Delivery of the Quad-Helix Appliance. Am J Orthod Dentofacial Orthop. 1988 Oct;94(4):311-6.

Vargo J, Buschang PH, Boley JC, English JD, Behrents RG, Owen AH, 3rd. Treatment Effects and Short-Term Relapse of Maxillomandibular Expansion During the Early to Mid Mixed Dentition. Am J Orthod Dentofacial Orthop. 2007 Apr;131(4):456-63.

Wertz RA. Skeletal and Dental Changes Accompanying Rapid Midpalatal Suture Opening. Am J Orthod. 1970 Jul;58(1):41-66.

Yatabe MS, Ozawa TO, Janson G, Faco RA, Garib DG. Are There Bone Dehiscences in Maxillary Canines Orthodontically Moved into the Grafted Alveolar Cleft? Am J Orthod Dentofacial Orthop. 2015 Feb;147(2):205-13. 

Anexos 

ANEXO 1 - Ofício de aprovação pelo Comitê de Ética em Pesquisa

\section{FACULDADE DE ODONTOLOGIA DE BAURU- USP}

\section{PARECER CONSUBSTANCIADO DO CEP}

\section{DADOS DO PROJETO DE PESQUISA}

Titulo da Pesquisa: Alteraçōes dento-alveolares em adultos promovida pelo uso de arco auxiliar de expansão em TMA avaliadas por meio de tomografias computadorizadas.

Pesquisador: Gustavo Siecola

Área Temática:

Versảo: 2

CAAE: 48649515.2 .0000 .5417

Instituição Proponente: Universidade de São Paulo - Faculdade de Odontologia de Baun

Patrocinador Principal: Financiamento Próprio

\section{DADOS DO PARECER}

Número do Parecer: 1.292 .307

Apresentação do Projeto:

Idem ao parecer 1.235.542.

Objetivo da Pesquisa:

Idem ao parecer 1.235.542.

Avaliação dos Riscos e Beneficios:

Idern ao parecer 1.235.542.

Comentários e Consideraçōes sobre a Pesquisa:

Idem ao parecer 1.235.542.

Consideraçōes sobre os Termos de apresentação obrigatória:

Os termos de apresentação foram apresentados no entanto o TCLE não contém a alinea h referente à indenização, mesmo sendo pesquisa retrospectiva.

PENDÉNCIA ATENDIDA.

\section{Recomendaçōes:}

No projeto não está descrita a justificação (segundo legislaçăo brasileira) para a realizaçăo das tomografiasnos participantes, no caso duas tomografias.

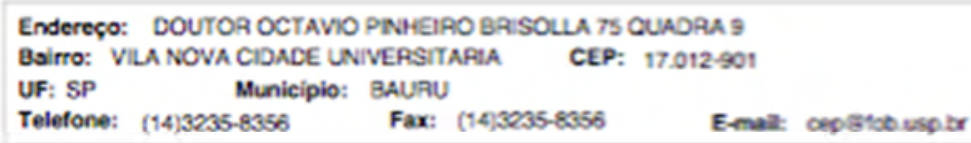




\section{FACULDADE DE ODONTOLOGIA DE BAURU- USP}

Continuacto do Pareoer: 1.292 .307

O pesquisador envia um oficio com a justificativa para as tomografias segundo critério clinico e severidade do caso.

Conclusōes ou Pendências e Lista de Inadequaçōes:

Pendências atendidas.

Consideraçōes Finais a critério do CEP:

Esse projeto foi considerado APROVADO na reuniảo ordinária do CEP de 21.10.2015, com base nas normas éticas da Resolução CNS 466/12. A0 término da pesquisa o CEP.FOB/USP exige a apresentaçã̃o de relatório final. Os relatórios parciais deverảo estar de acordo com o cronograma e/ou parecer emitido pelo CEP. Alteraçōes na metodologia, titulo, inclusão ou exclusão de autores, cronograma e quaisquer outras mudanças que sejam significativas deverāo ser previamente comunicadas a este CEP sob risco de nẫo aprovação do relatório final. Quando da apresentaçăo deste, deverảo ser incluidos todos os TCLEs e/ou termos de doaçăo assinados e rubricados, se pertinentes.

Este parecer foi elaborado baseado nos documentos abaixo relacionados:

\begin{tabular}{|c|c|c|c|c|}
\hline Tipo Documento & Arquivo & Postagem & Autor & Sîtuação \\
\hline $\begin{array}{l}\text { Informaçōes Básicas } \\
\text { do Proiato }\end{array}$ & $\begin{array}{l}\text { PB_INFORMACYES_BASICAS_DO_P } \\
\text { ROJETO } 574854 \text { odf }\end{array}$ & $\begin{array}{c}02 / 10 / 2015 \\
17: 11: 11\end{array}$ & & Aceito \\
\hline $\begin{array}{l}\text { Recurso Anexado } \\
\text { pelo Pesquisador }\end{array}$ & RespostaParecer2.pdf & $\begin{array}{c}02 / 10 / 2015 \\
17: 1039\end{array}$ & Gustavo Siecola & Aceitio \\
\hline $\begin{array}{l}\text { TCLE / Termos de } \\
\text { Assentimento / } \\
\text { Justificativa de } \\
\text { Ausência }\end{array}$ & TCLE2.pdf & $\begin{array}{c}02 / 10 / 2015 \\
17: 08: 50\end{array}$ & Gustavo Siecola & Aceito \\
\hline $\begin{array}{l}\text { Projeto Detalhado / } \\
\text { Brochura } \\
\text { Investigader }\end{array}$ & PROJETO2.pdf & $\begin{array}{c}02 / 10 / 2015 \\
17: 07533\end{array}$ & Gustavo Siecola & Aceito \\
\hline Outros & Pesquisador.pdf & $\begin{array}{c}27 / 0822015 \\
15 \times 59-51\end{array}$ & Gustavo Siecola & Aceito \\
\hline Outros & Questionario.pdf & $\begin{array}{c}27 / 08 / 2015 \\
15-5534\end{array}$ & Gustavo Siecola & Aceito \\
\hline $\begin{array}{l}\text { Declaração de } \\
\text { Instituiçẫo e } \\
\text { Infraestrutura }\end{array}$ & Encaminhamento.pdf & $\begin{array}{c}27 / 08 / 2015 \\
15: 51: 49\end{array}$ & Gustavo Siecola & Aceito \\
\hline Folha de Rosto & FolhaRosto.pdf & $\begin{array}{c}27 / 0822015 \\
15: 38: 37\end{array}$ & Gustavo Siecola & Aceito \\
\hline
\end{tabular}

Enderę̧: DOUTOR OCTAVIO PNHEIRO BRISOUA 7S QUAORA 9 Boirro: VILA NOVA CIDACE UNIVERSITAPIA CEP: $17.012-901$

UF: SP Municipio: BAURU

Telefone: (14)3235-8356 Fax: (14)3e35-8a56 E-mal: cepatobuspor 


\section{FACULDADE DE ODONTOLOGIA DE BAURU- USP}

Contruacle co Pareoer: 1.292 .907

Situação do Parecer:

Aprovado

Necessita Apreciação da CONEP:

Não

BAURU, 22 de Outubro de 2015

Assinado por:

Izabel Regina Fischer Rubira Bullen

(Coordenador)

Enderoç: DOUTOR OCTAVIO PRHERO BRSOUA 75 QUAORA 9

Boirro: VILA NOVA CIDACE UNIVERSTTARIA CEP: $17.012-901$

UF: SP Municipio: BAURU

Telefone: (14)3e35-8356 Fax: (19)3e35-8356 E-mali: cepatobuspor 
ANEXO 2 - Termo de consentimento livre e esclarecido

\section{TERMO DE CONSENTIMENTO LIVRE E ESCLARECIDO}

Eu, Gustavo Silva Siécola, cirurgião-dentista sob registro CRO-SP 78624, venho convidar o(a) $\operatorname{Sr}(a)$.

a participar da

pesquisa intitulada "Alterações dento-alveolares em adultos promovida pelo uso de arco auxiliar de expansão em TMA avaliadas por meio de tomografias computadorizadas", na qual sou responsável e orientada pelo Prof. Dr. José Fernando Castanha Henriques, para obtenção do titulo de Doutor em Ortodontia pela Faculdade de Odontologia de Bauru - FOB / USP.

Este trabalho consiste em utilizar os exames já realizados para início do tratamento ortodôntico, bem como os realizados durante o mesmo. Dentre estes exames estão as fotografias extra e intra bucais (de dentro e fora da boca), radiografias iniciais, modelos de gesso e os exames de tomografias computadorizadas realizadas antes e depois da utilização do arco duplo de expansão (arco mais espesso utilizado em conjunto com o arco preso aos bráquetes / "quadradinhos"). Estes exames e os resultados oriundos desta pesquisa serão de utilização apenas para fins científicos, podendo ser publicados em meios de divulgação cientifica como jornais, revistas e apresentação em seminários, aula entre outras. Desta forma, nenhum exame ou intervenção ortodôntica diferente da prevista ao tratamento ortodôntico será realizado apenas para intuito da pesquisa, não tendo, portanto, alteração no custo ou tempo de tratamento previsto. Assim, os benefícios em participar desta pesquisa visa permitir identificar e descrever os resultados da mecânica ortodôntica com arco duplo de expansão em nível de tomografia computadorizada, sem qualquer prejuízo ao participante, já que esta mecânica já é utilizada com análises clínicas.

A qualquer momento durante a execução das análises dos exames e por qualquer motivos, o(a) $\mathrm{Sr}(a)$ pode requisitar ser excluído da amostra, sem qualquer tipo de penalidade, custo ou alteração no tratamento ortodôntico previsto incialmente. Desta mesma forma, será mantido sigilo das informações pessoais durante e após a execução desta pesquisa, sendo apenas divulgados os resultados. Por se tratar de uma pesquisa utilizando apenas exames já realizados, esta não trará qualquer risco, dano ou possibilidade de prejuízo para o participante. Mesmo assim, o pesquisador se encontra a disposição para qualquer assistência durante a realização desta pesquisa.

Como comprovação do acima descrito, o(a) Sr(a) receberá uma cópia deste termo no ato da assinatura do mesmo, como as mesmas informações e descrições. 
Pelo presente instrumento que atende às exigências legais, o Sr. (a) portador da cédula

de identidade , após leitura minuciosa das informações constantes neste TERMO DE CONSENTIMENTO LIVRE E ESCLARECIDO, devidamente explicada pelos profissionais em seus mínimos detalhes, ciente dos serviços e procedimentos aos quais será submetido, não restando quaisquer dúvidas a respeito do lido e explicado, DECLARA e FIRMA seu CONSENTIMENTO LIVRE E ESCLARECIDO concordando em participar da pesquisa proposta. Fica claro que o participante da pesquisa, pode a qualquer momento retirar seu CONSENTIMENTO LIVRE E ESCLARECIDO e deixar de participar desta pesquisa e ciente de que todas as informações prestadas tornar-se-ão confidenciais e guardadas por força de sigilo profissional (Art. $9^{\circ}$ do Código de Ética Odontológica).

Por fim, como pesquisador(a) responsável pela pesquisa, DECLARO o cumprimento do disposto na Resolução CNS n 466 de 2012, contidos nos itens IV.3, item IV.5.a e na íntegra com a resolução CNS n 466 de dezembro de 2012.

Por estarmos de acordo com o presente termo o firmamos em duas vias igualmente válidas (uma via para o participante da pesquisa e outra para o pesquisador) que serão rubricadas em todas as suas páginas e assinadas ao seu término, conforme o disposto pela Resolução CNS n 466 de 2012, itens IV.3.f e IV.5.d.

Bauru, SP, de de 
O Comitê de Ética em Pesquisa - CEP, organizado e criado pela FOB-USP, em 29/06/98 (Portaria GD/0698/FOB), previsto no item VII da Resolução CNS n 466/12 do Conselho Nacional de Saúde do Ministério da Saúde (publicada no DOU de 13/06/2013), é um Colegiado interdisciplinar e independente, de relevância pública, de caráter consultivo, deliberativo e educativo, criado para defender os interesses dos participantes da pesquisa em sua integridade e dignidade e para contribuir no desenvolvimento da pesquisa dentro de padrões éticos.

Qualquer denúncia e/ou reclamação sobre sua participação na pesquisa poderá ser reportada a este CEP:

\section{Horário e local de funcionamento:}

Comitê de Ética em Pesquisa

Faculdade de Odontologia de Bauru-USP - Prédio da Pós-Graduação (bloco E - pavimento superior), de segunda à sexta-feira, no horário das $14 \mathrm{hs}$ às 17 horas, em dias úteis.

Alameda Dr. Octávio Pinheiro Brisolla, 9-75

Vila Universitária - Bauru - SP - CEP 17012-901

Telefone/FAX(14)3235-8356

e-mail: cep@fob.usp.br

Qualquer dúvida ou necessidade de esclarecimento sobre o andamento da pesquisa e / ou tratamento, entre em contato com o pesquisador:

Gustavo Silva Siécola

Clinica Corporal Line

Rua Bartolomeu de Gusmão, 8-85

Jardim América - Bauru - SP - CEP 17017-336

Telefone: 14 3234-4243 / 3214-4688

E-mail: siecolaortodontia@gmail.com 